\title{
Holocene variability in sea ice and primary productivity in the northeastern Baffin Bay
}

\author{
Jeetendra Saini ${ }^{1}$ (D) $\cdot$ Ruediger Stein ${ }^{1,2} \cdot$ Kirsten Fahl $^{1} \cdot$ Jens Weiser $^{2} \cdot$ Dierk Hebbeln $^{2} \cdot$ Claude Hillaire-Marcel $^{3}$. \\ Anne de Vernal $^{3}$
}

Received: 2 October 2019 / Accepted: 4 February 2020 / Published online: 25 February 2020

(c) The Author(s) 2020

\begin{abstract}
Arctic sea ice is a critical component of the climate system, known to influence ocean circulation, earth's albedo, and ocean-atmosphere heat and gas exchange. Current developments in the use of $\mathrm{IP}_{25}$ (a sea ice proxy with 25 carbon atoms only synthesized by Arctic sea ice diatoms) have proven it to be a suitable proxy for paleo-sea ice reconstructions over hundreds of thousands to even millions of years. In the NE Baffin Bay, off NW Greenland, Melville Bugt is a climate-sensitive region characterized by strong seasonal sea ice variability and strong melt-water discharge from the Greenland Ice Sheet (GIS). Here, we present a centennial-scale resolution Holocene sea ice record, based on $\mathrm{IP}_{25}$ and open-water phytoplankton biomarkers (brassicasterol, dinosterol and HBI III) using core GeoB19927-3 (73 35.26 N, 58 ${ }^{\circ} 05.66^{\prime} \mathrm{W}$ ). Seasonal to ice-edge conditions near the core site are documented for most of the Holocene period with some significant variability. In the lower-most part, a cold interval characterized by extensive sea ice cover and very low local productivity is succeeded by an interval ( 9.4-8.5 ka BP) with reduced sea ice cover, enhanced GIS spring melting, and strong influence of the West Greenland Current (WGC). From $\sim 8.5$ until $~ 7.8 \mathrm{ka} \mathrm{BP,} \mathrm{a} \mathrm{cooling} \mathrm{event} \mathrm{is} \mathrm{recorded} \mathrm{by} \mathrm{ice} \mathrm{algae} \mathrm{and} \mathrm{phytoplankton} \mathrm{bio-}$ markers. They indicate an extended sea ice cover, possibly related to the opening of Nares Strait, which may have led to an increased influx of Polar Water into NE-Baffin Bay. The interval between $\sim 7.8$ and $\sim 3.0 \mathrm{ka} \mathrm{BP}$ is characterized by generally reduced sea ice cover with millennial-scale variability of the (late winter/early spring) ice-edge limit, increased open-water conditions (polynya type), and a dominant WGC carrying warm waters at least as far as the Melville Bugt area. During the last $3.0 \mathrm{ka} \mathrm{BP}$, our biomarker records do not reflect the late Holocene 'Neoglacial cooling' observed elsewhere in the Northern Hemisphere, possibly due to the persistent influence of the WGC and interactions with the adjacent fjords. Peaks in HBI III at about $\sim 2.1$ and $\sim 1.3 \mathrm{ka} \mathrm{BP}$, interpreted as persistent ice-edge situations, might correlate with the Roman Warm Period (RWP) and Medieval Climate Anomaly (MCA), respectively, in-phase with the North Atlantic Oscillation (NAO) mode. When integrated with marine and terrestrial records from other circum-Baffin Bay areas (Disko Bay, the Canadian Arctic, the Labrador Sea), the Melville Bugt biomarker records point to close ties with high Arctic and Northern Hemispheric climate conditions, driven by solar and oceanic circulation forcings.
\end{abstract}

Keywords Holocene $\cdot$ Baffin bay $\cdot$ Sea ice $\cdot \mathrm{IP}_{25} \cdot \mathrm{HBI}$ III $\cdot$ Brassicasterol $\cdot \mathrm{PIP}_{25}$ index

Electronic supplementary material The online version of this article (https://doi.org/10.1007/s41063-020-00075-y) contains supplementary material, which is available to authorized users.

Jeetendra Saini

jeetendra.saini@awi.de

1 Alfred Wegener Institute Helmholtz Centre for Polar and Marine Research, Bremerhaven, Germany

2 Marum-Center for Marine Environmental Sciences, University of Bremen, Bremen, Germany

3 Université du Québec à Montréal, Montreal, Canada

\section{Introduction}

Polar regions in the Northern Hemisphere, especially the Arctic and Greenland areas, are undergoing dramatic changes due to an accelerating reduction in sea ice cover and ice sheet extent for the past three-four decades. Since the late 70s, the Arctic sea ice cover has decreased rapidly $[57,94]$. The summer sea ice extent and thickness of multi-year ice are decreasing at the fastest rate ever observed during recent times $(-8.6 \%$ per decade), and model simulations suggest that Arctic summer sea ice may 
disappear within the next 50 or even 30 years $[43,114$, $118,130]$. Given the magnitude of the ongoing reduction in the sea ice cover, information on its impact on water mass circulation and related natural climate conditions over longer time scales is important, notably for the testing of predictive climate models. However, historical and satellite records only span a few centuries or decades, respectively [94, 128], thus limiting the understanding of natural variability of sea ice, emphasizing the need for high-resolution multi-proxy records of its past variations [53, 81]. Reliable long-term, at least semi-quantitative sea ice reconstructions are, thus, needed for the validation of Arctic climate scenarios [25, 28]. Furthermore, the ongoing enhanced melting of the Greenland Ice Sheet (GIS), and its significant contribution $\left(\sim 0.34 \mathrm{~mm} \mathrm{year}^{-1}\right)$ [102] to global annual sea-level rise $\left(\sim 3.3 \mathrm{~mm} \mathrm{year}^{-1}\right)$ [23], also needs to be appraised in relation to natural processes that occurred at millennial to centennial time scales during the present interglacial.

Northern Baffin Bay (Fig. 1A) is of particular interest due to the interaction of the relatively warm high-salinity West Greenland Current (WGC) water with the cold polar water of the Baffin Current (BC) originating from the Arctic Ocean, resulting in the presence of the high productivity North Water Polynya (NWP) kept open by winds, tides and ice bridges [5]. Eastward of the polynya, Melville Bugt borders the heavily glaciated NW Greenland region, only separated by narrow fringes of ice-free islands, nunataks, and peninsulas. Fast-flowing $\left(>1000 \mathrm{~m} \mathrm{a}^{-1}\right)$ glaciers such as Ussing Braeer and Cornell glaciers are in close proximity to Melville Bugt [54, 102, 133]. Marine sedimentary archives from this area may, thus, provide records of sea ice and past ice sheet dynamics in this highly climate-sensitive area. So far, the sea ice variability and long-term changes in water masses of the NE-Baffin Bay, especially the WGC, as well as the impact of melt-water discharge from the GIS that occurred since deglaciation, all remain barely documented $[18,22,41]$.

The present study aims at filling this gap. It is based on a detailed analysis of a 11.5-m-long gravity core from the southern Melville Bugt (core GeoB19927-3; Fig. 1A) spanning a time interval of the last approximately $10 \mathrm{ka} \mathrm{BP}$. Special attention is paid to the high-resolution reconstruction of sea ice conditions, mainly documented from the abundance and flux of $\mathrm{IP}_{25}$ and open-water phytoplankton biomarkers (brassicasterol, dinosterol and HBI III) and sand content (grain size). These data are complemented by information about the core lithology and dry bulk density, as well as additional published paleoclimate records from circumBaffin Bay areas.
Fig. 1 A Bathymetric map of the Baffin Bay and the location of sediment core GeoB19927 from southern Melville Bugt. A schematic modern surface circulation system in Baffin Bay and around Greenland is also shown, i.e., WGC-West Greenland Current, BC-Baffin Current, IC-Irminger Current, LC-Labrador Current and EGCEast Greenland Current. The area marked with the dotted black line indicates the approximate extent of the North Water Polynya, and the solid white triangle, hexagon, and diamond indicate the location of Cores AMD14-Kane2B (Kane Basin), AMD14-204C (Upernavik), and MSM343300 (Disko Bay), respectively. B Satellite-based modern, monthly sea ice concentrations in (\%, 1978-2015 [24]; updated 2015) in Baffin Bay for (a) winter (Jan-Mar), (b) spring (Apr-Jun), (c) summer (Jul-Sept), and (d) autumn (Oct-Dec), adapted from Kolling et al. [62]. The white dot indicates the position of Core GeoB19927, and the white diamond indicates the location of core MSM343300 in Disko Bay

\section{Biomarker proxies for paleo-environmental reconstruction}

Paleo-sea ice reconstructions rely heavily on proxy-based methods. In this context, combination of proxies (i.e., sedimentological, biogeochemical and micropaleontological) preserved in marine sediments such as ice-rafted debris, assemblages of diatoms, dinocysts and ostracods as well as $\delta^{18} \mathrm{O}$ in foraminiferal tests may provide indirect information about past sea ice conditions (e.g., [27-29, 40, 42, 50, $73,83,98,131])$. However, microfossil records such as, for example, diatom assemblages must be interpreted with caution as they may also be influenced by dissolution and selective preservation $[14,72,110]$.

As a more direct approach, the "sea ice proxy $\mathrm{IP}_{25}$ ", after its first introduction in a pioneer study by Belt et al. [7], has been preferentially used for reconstructing the variability of sea ice in the Arctic region (see [10] for a recent review). $\mathrm{IP}_{25}$ is a highly branched isoprenoid (HBI) alkene with 25 carbon atoms, derived from specific sea ice diatoms (mostly Haslea spp.) living in/under first-year ice and in brine channels $[7,8,20]$. As $\mathrm{IP}_{25}$ preserves well in the sediments and is resistant to degradation, it was possible to reconstruct sea ice variability dating back to hundreds of thousands to even millions of years ago [58, 65, 116, 117].

Further, an even more reliable and detailed picture is achieved when combining $\mathrm{IP}_{25}$ with open-water phytoplankton biomarkers such as brassicasterol, dinosterol and/ or a tri-unsaturated HBI (Z-isomer; hereinafter referred to as "HBI III") and its E-isomer [9, 12, 87, 89, 90, 112, 126, 134]. In this way, the problem of distinguishing perennial ice cover from ice-free water can be solved. The absence or low values of both $\mathrm{IP}_{25}$ and phytoplankton biomarkers indicate a more permanent ice cover, whereas a minimal (to zero) $\mathrm{IP}_{25}$ and high phytoplankton biomarkers are indicative of ice-free 

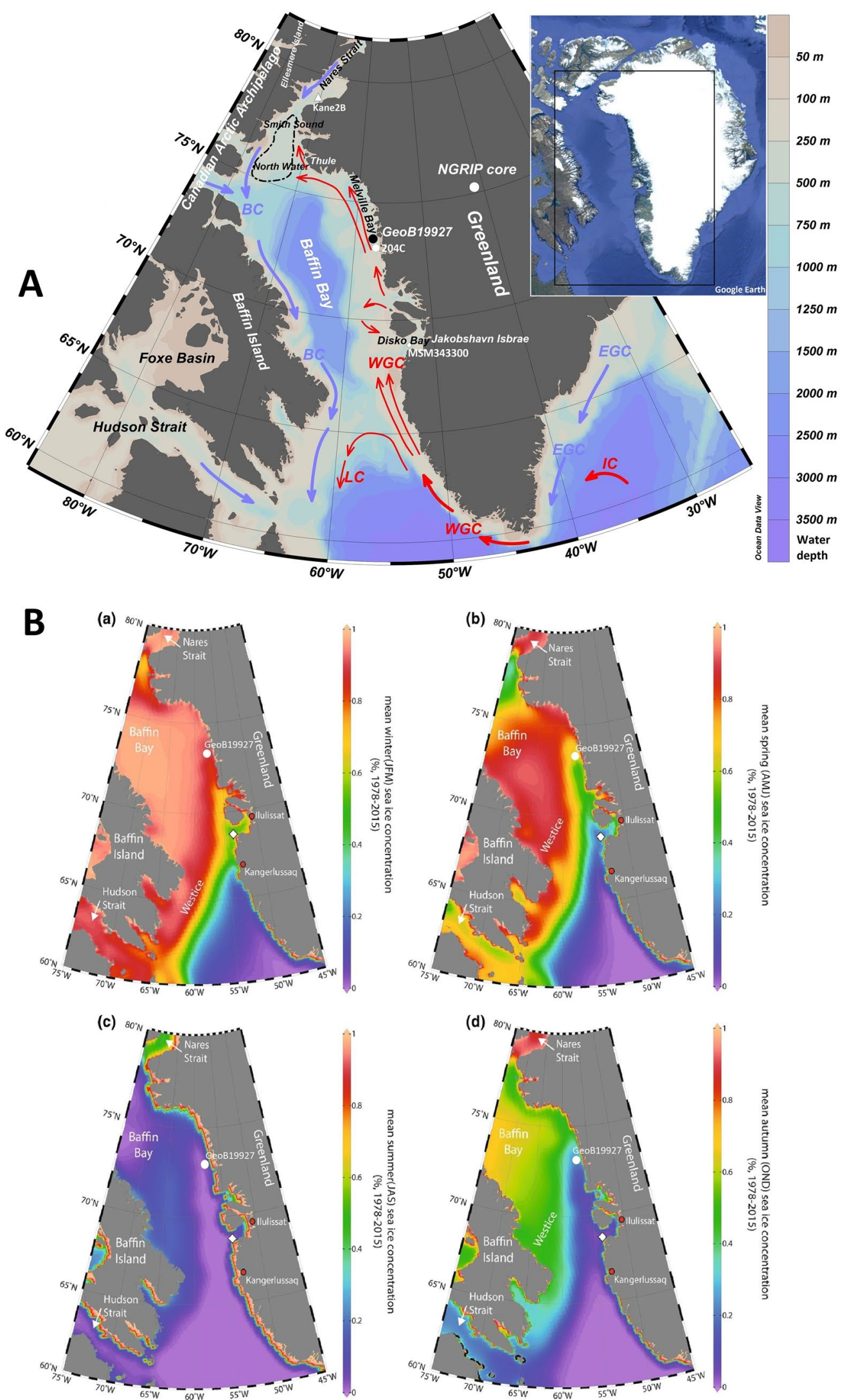
conditions, and a variable amount of these biomarkers may reflect changing seasonal sea ice cover. This approach has been successfully applied to sediments from the Fram Strait, the central Arctic Ocean, and Arctic marginal seas to reconstruct sea ice conditions during late Quaternary times (e.g., $[12,13,36,87,88])$, for the most recent review with pros and cons of this approach see [10].

The use of different phytoplankton biomarkers (in combination with $\mathrm{IP}_{25}$ ) may even allow distinguishing between different seasonal sea ice conditions including marginal ice zone (MIZ) situations (e.g., [9, 12, 103]). Based on the distribution pattern of HBI III in surface sediments from the western Barents Sea and the correlation with seasonal sea ice concentration maps, for example, Belt et al. [12] proposed that HBI III maxima reflect winter MIZ conditions. Based on a study of East Greenland fiords surface sediments, on the other hand, Ribeiro et al. [103] proposed that HBI III maxima correlate with the July MIZ situation. Based on biomarker investigations of surface sediments across Baffin Bay and the correlation with modern satellite observations, Kolling [61] suggested that the sea ice indices $\mathrm{P}_{\mathrm{D}} \mathrm{IP}_{25}$ and $\mathrm{P}_{\mathrm{B}} \mathrm{IP}_{25}$ may record the late spring and/or autumn conditions, whereas $\mathrm{P}_{\mathrm{III}} \mathrm{IP}_{25}$ index may reflect more the late winter/early spring (ice-edge) conditions in the Baffin Bay. Furthermore, Belt et al. [9] recently suggested that the proportions of triunsaturated HBIs; $\mathrm{Z}$ and E-isomer $\left(\mathrm{TR}_{25}\right)$ may indicate spring phytoplankton blooms, at least for the Barents Sea region. This approach, however, needs to be further evaluated using additional data from surface sediments and sediment cores from other Arctic regions.

\section{Environmental setting}

Melville Bugt is part of the broad shelf area in NE Baffin Bay (Fig. 1A) covering ca. $120,000 \mathrm{~km}^{2}$ in the $200-\mathrm{km}$-wide continental shelf offshore NW Greenland. Baffin Bay acts as a pathway for sea ice and fresh-water exchange between the Arctic and North Atlantic Oceans. The oceanographic circulation in Baffin Bay (Fig. 1A) is characterized by the WGC ( 150-1330-m water depth), flowing northwards along the west coast of Greenland and the cold BC $(\sim 100-300-\mathrm{m}$ water depth) flowing southward and originating from the Arctic Ocean [119]. The WGC is formed by a combination of: (1) Atlantic sourced, relatively warm and saline water from the Irminger Current (IC), (2) polar sourced cold, low salinity water from the East Greenland Current (EGC) and (3) local melt-water discharge along the SW Greenland coast (Fig. 1A) [119]. The WGC near Melville Bugt is believed to split into two branches, one turning west that joins the BC near Smith Sound and the other branch circulating towards Nares Strait [21, 105].
This area displays high seasonal sea ice variability, especially the Melville Bugt area off West Greenland (Fig. 1B). In winter, this area is almost completely ice-covered as the sea ice margin, the so-called 'Westice', expands further southwards $[113,119]$. In summer, however, the area becomes almost ice free. The ecological setting of Melville Bugt is highly affected by outlet glaciers of the GIS and receives about $\sim 27 \%$ of GIS drainage [102]. Wind stresses here are highly seasonal with stronger wind stress in winter compared to summer [119].

During the Last Glacial Maximum (LGM), the extended Greenland, Laurentide, and Innuitian ice sheets (GIS, LIS and IIS, respectively) stretched across Baffin Bay coast to the shelf edge as demonstrated by the presence of crossshelf troughs $[38,92,111]$. Although no geochronological records are currently available for the onset of deglaciation in Melville Bugt, numerical modeling data suggest the onset of deglaciation occurred as early as at $\sim 16.0 \mathrm{ka}$ BP [69]. However, the general-present day like ocean mass circulations were probably established in the central-eastern Baffin Bay 14 ka BP and by 10.4-9 ka BP in northern Baffin Bay [71, 109]. The opening of Nares Strait $\sim 9 \mathrm{ka}$ BP allowed the connection between Baffin Bay and the Arctic Ocean, which led to the establishment of the modern ocean circulations in the Baffin Bay $[39,48,52]$. The sediments deposited at the seafloor of Baffin Bay are predominantly derived from glacial erosion of the surrounding land masses, and high sedimentation rates of $40-140 \mathrm{~cm} \mathrm{ka}^{-1}$ make this area an ideal site for paleoenvironmental studies [115].

\section{Material and methods}

\section{Field methods}

The current study is based on the analysis of the $1147-\mathrm{cm}-$ long gravity core GeoB19927-3 (Fig. 1A; black circle) (Lat: $73^{\circ} 35.26^{\prime} \mathrm{N}$; Lon: 58 05.66' W; Water depth: $932 \mathrm{~m}$ ), recovered from southern Melville Bugt during the RV Maria S. Merian cruise MSM44 (BAFFEAST) in June/July 2015 [31]. The working half of the core was sampled and divided into four sets of samples. One set was freeze-dried for biomarker analysis (5-10-cm resolution in this study) and the second set was used for dating (foraminifera and ${ }^{210} \mathrm{~Pb}$ ). The other two sets were stored at $+4{ }^{\circ} \mathrm{C}$ for other multi-proxy analyses (i.e., dinoflagellates, foraminifera, and provenance studies).

\section{Chronology/age model}

Age control is provided through a combination of radiocarbon and ${ }^{210} \mathrm{~Pb}$-dating, followed by Bayesian age modeling. 
Table 1 Results of the radiocarbon dating on core GeoB19927-3

\begin{tabular}{|c|c|c|c|c|c|c|c|c|c|}
\hline Sample ID & Lab ID & Depth (cm) & ${ }^{14} \mathrm{C}$-age (year) & $\begin{array}{l}{ }^{14} \mathrm{C} \text {-error } \\
\text { (years) }\end{array}$ & Weight (mg) & Material & $\begin{array}{l}\text { Min age } \\
\text { (years } \\
\text { BP) }\end{array}$ & $\begin{array}{l}\text { Max age } \\
\text { (years } \\
\text { BP) }\end{array}$ & $\begin{array}{l}\text { Mean age } \\
\text { (years } \\
\text { BP) }\end{array}$ \\
\hline $\begin{array}{c}\text { GeoB19927- } \\
\text { 3_33cm }\end{array}$ & AWI-1468.1.1 & 33 & 1821 & 176 & 0.69 & $\begin{array}{l}\text { Mixed benthic } \\
\text { forams }\end{array}$ & 557 & 1348 & 970 \\
\hline $\begin{array}{l}\text { GeoB19927- } \\
\text { 3_62cm }\end{array}$ & AWI-1469.1.1 & 62 & 2072 & 177 & 0.62 & $\begin{array}{l}\text { Mixed benthic } \\
\text { forams }\end{array}$ & 1027 & 1764 & 1408 \\
\hline $\begin{array}{c}\text { GeoB19927- } \\
\text { 3_199cm }\end{array}$ & Poz-85919 & 199 & 3360 & 30 & 15 & Mollusk shells & 2818 & 3190 & 3009 \\
\hline $\begin{array}{c}\text { GeoB19927- } \\
\text { 3_410cm }\end{array}$ & AWI-1259.1.1 & 410 & 4692 & 197 & 0.8 & $\begin{array}{l}\text { Mixed benthic } \\
\text { forams }\end{array}$ & 4478 & 5122 & 4799 \\
\hline $\begin{array}{c}\text { GeoB19927- } \\
\text { 3_411cm }\end{array}$ & AWI-1261.1.1 & 411 & 4836 & 192 & 1 & $\begin{array}{l}\text { Mixed benthic } \\
\text { forams }\end{array}$ & 4489 & 5127 & 4807 \\
\hline $\begin{array}{c}\text { GeoB19927- } \\
\text { 3_538cm }\end{array}$ & Poz-85920 & 538 & 5495 & 35 & 10 & Mollusk shells & 5618 & 5901 & 5764 \\
\hline $\begin{array}{c}\text { GeoB19927- } \\
\text { 3_561cm }\end{array}$ & Poz-85921 & 561 & 5720 & 35 & 12 & Mollusk shells & 5803 & 6062 & 5994 \\
\hline $\begin{array}{c}\text { GeoB19927- } \\
\text { 3_607cm }\end{array}$ & Poz-85924 & 607 & 5885 & 35 & 10 & Mollusk shells & 6094 & 6369 & 6222 \\
\hline $\begin{array}{c}\text { GeoB19927- } \\
\text { 3_689cm }\end{array}$ & Poz-85925 & 689 & 6670 & 50 & 10 & Mollusk shells & 6821 & 7219 & 7028 \\
\hline $\begin{array}{c}\text { GeoB19927- } \\
\text { 3_767cm }\end{array}$ & Poz-85926 & 767 & 7410 & 10 & 10 & Mollusk shells & 7584 & 7893 & 7740 \\
\hline $\begin{array}{c}\text { GeoB19927- } \\
\text { 3_790cm }\end{array}$ & Poz-85927 & 790 & 7640 & 50 & 10 & Mollusk shells & 7801 & 8071 & 7938 \\
\hline $\begin{array}{c}\text { GeoB19927- } \\
\text { 3_1000cm }\end{array}$ & AWI-1260.1.1 & 1000 & 8831 & 205 & 0.8 & $\begin{array}{l}\text { Planktonic ( } N \text {. } \\
\text { pachyderma } \\
\text { sin.) and mixed } \\
\text { benthic }\end{array}$ & 8956 & 9876 & 9371 \\
\hline
\end{tabular}

Minimum and maximum ages denote the $95 \%(2 \sigma)$ uncertainty of the BACON age model

Accelerator Mass Spectrometry (AMS) ${ }^{14} \mathrm{C}$-dating was performed on 12 samples, partially on mollusc shell fragments, partially on mixed benthic foraminifera (in one case mixed with specimens of the planktic foraminifera Neogloboquadrina pachyderma sin.) (see Table 1 for details). Mollusc fragments were measured at the Poznan Radiocarbon Laboratory, Poland; whereas, the foraminifera were dated at the MICADAS facility at the Alfred-Wegener-Institute in Bremerhaven, Germany. The larger mollusc fragments were measured as graphite, whereas a novel technology for very small sample sizes was used for the foraminifera picked from the $>100 \mu \mathrm{m}$ fraction. Here, the $\mathrm{CO}_{2}$ released from the foraminiferal carbonate upon acid treatment is directly analyzed with a compact AMS facility equipped with a hybrid ion source (for a detailed explanation, see [127]. Radionuclide analyses $\left({ }^{210} \mathrm{~Pb},{ }^{40} \mathrm{~K},{ }^{137} \mathrm{Cs}\right)$ were performed at the Bremen State Radioactivity Measurements Laboratory on a total of seven one-cm slices of sediment.

The final age model was constructed using the software package $B A C O N$ [15], written as open-source code for the statistical computation program 'R'. BACON uses a Bayesian approach to determine the most likely age-depth relation, resulting in greater flexibility regarding, e.g., the accumulation rates between two dating points. Prior to the actual age modeling, all radiocarbon dates were converted into calendar ages using the Marine 13-calibration curve as proposed by Reimer et al. [100] with the built-in calibration function of the program.

Using historical, pre-bomb samples, Lloyd et al. [76] estimated a local reservoir correction of $140 \pm 35$ years for the Disko Bay area. This value has been discussed in more detail in Jackson et al. [45] and widely accepted in previous studies $[51,76,96,97]$ and was, therefore, applied here in the same manner during the calibration.

\section{Bulk parameters (TOC and sand content)}

Freeze-dried and homogenized sediments were taken $(5-\mathrm{cm}$ intervals) for total organic carbon (TOC) measurement using a Carbon-Sulfur ELTRA Analyser (CS-800, ELTRA) after removal of carbonates by adding hydrochloric acid (37\%, $500 \mu \mathrm{l})$. The machine was calibrated with a standard before measurements, and the accuracy of these measurements was controlled by additional standard measurements after every 10 samples, the error of our TOC measurements is at $\pm 0.02 \%$. 
Sand content (grain size) measurements were performed at $10-30-\mathrm{cm}$ resolution at the Particle-Size Laboratory at MARUM, University of Bremen with a Beckman Coulter Laser Diffraction Particle Size Analyzer LS 13320. The obtained results provide the particle-size distribution of a sample from 0.04 to $2000 \mu \mathrm{m}$, and the sand content class used was between 63 and $2000 \mu \mathrm{m}$. The average standard deviation integrated over all size classes $(63-2000 \mu \mathrm{m})$ is better than \pm 4 vol\%. (cf., [6] for a detailed explanation).

\section{Sea ice biomarkers (IP ${ }_{25}, \mathrm{HBI}$ III and sterols)}

For biomarker analysis, $\sim 4 \mathrm{~g}$ of freeze-dried and homogenized sediment (10-cm intervals) was extracted using dichloromethane:methanol $(2: 1 \mathrm{v} / \mathrm{v})$ as solvent for ultrasonication $(3 \times 15 \mathrm{~min})$. Beforehand, 9-octylheptadec-8-ene (9-OHD; $0.1 \mu \mathrm{g} / \mathrm{sample})$, 7-hexylnonadecane (7-HND; $0.076 \mu \mathrm{g} / \mathrm{sample}), 5 \alpha$-androstan-3 $\beta$-ol (Androstanol; $10.7 \mu \mathrm{g} /$ sample) and 2,6,10,15,19,23-hexamethyltetracosane (Squalane; $3.2 \mu \mathrm{g} / \mathrm{sample}$ ) were added for biomarker quantification. Sterols and hydrocarbons were separated by open silica $\left(\mathrm{SiO}_{2}\right)$ column chromatography with $n$-hexane $(5 \mathrm{ml})$ and ethyl-acetate: $n$-hexane $(9 \mathrm{ml}, 2: 8 \mathrm{v} / \mathrm{v})$ as eluent. The latter fraction was silylated with $200 \mu \mathrm{l}$ BSTFA (bis-trimethylsilyl-trifluoroacetamide) $\left(60^{\circ} \mathrm{C}, 2 \mathrm{~h}\right)$.

The identification of the compounds was carried out with a gas chromatograph (Agilent Technologies GC6850, $30 \mathrm{~m}$ DB-1MS column, $0.25 \mathrm{~mm}$ id, $0.25 \mu \mathrm{m}$ film) coupled to an Agilent Technologies 5977 C VL MSD mass selective detector (triple-axis Detector, $70 \mathrm{eV}$ constant ionization potential, Scan $50-550 \mathrm{~m} / \mathrm{z}, 1 \mathrm{scan} \mathrm{s}^{-1}$, ion source temperature $230^{\circ} \mathrm{C}$ ) for HBI and sterol. GC measurements were carried out with the following temperature program for the hydrocarbons: $60{ }^{\circ} \mathrm{C}(3 \mathrm{~min}), 150{ }^{\circ} \mathrm{C}\left(15^{\circ} \mathrm{C} \min ^{-1}\right), 320^{\circ} \mathrm{C}\left(10^{\circ} \mathrm{C} \min ^{-1}\right)$, $320^{\circ} \mathrm{C}\left(15\right.$-min isothermal) for the hydrocarbons and $60{ }^{\circ} \mathrm{C}$ (2 min $), 150{ }^{\circ} \mathrm{C}\left(15^{\circ} \mathrm{C} \mathrm{min}^{-1}\right), 320{ }^{\circ} \mathrm{C}\left(3{ }^{\circ} \mathrm{C} \mathrm{min}{ }^{-1}\right), 320{ }^{\circ} \mathrm{C}$ (20-min isothermal) for the sterols. Helium served as carrier

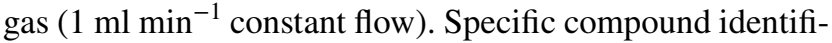
cation was based on the comparison of gas chromatography retention times with those of reference compounds and published mass spectra [7, 16, 19, 125]. For the quantification of $\mathrm{IP}_{25}$ and HBI III ( $\mathrm{Z}$ and E-isomer) their molecular ion $\left(\mathrm{m} / z, 350\right.$ for $\mathrm{IP}_{25}$ and $\mathrm{m} / \mathrm{z} 346$ for HBI III ' $\mathrm{Z}$ and E-isomer' in relation to the abundant fragment ion $\mathrm{m} / z, 266$ of internal standard (7-HND) was used (in selected ion monitoring mode, SIM). The different responses of these ions were balanced by an external calibration curve [36]. For the quantification of the sterols (quantified as trimethylsilyl ethers), the molecular ions $\mathrm{m} / \mathrm{z} 470$ for brassicasterol (as 24-methylcholesta-5,22E-dien-3 $\beta$-ol) and $m / z, 500$ for dinosterol ( $4 \alpha, 23,24 \mathrm{R}$-trimethyl-5 $\alpha$-cholest-22E-en-3 $\beta$-ol) were used in relation to the molecular ion $\mathrm{m} / \mathrm{z} 348$ for the internal standard Androstanol. All biomarker concentrations were either normalized to the organic carbon (TOC) content or converted to respective accumulation rates (or flux rates) (See data sets available at https://doi.pangaea.de/10.1594/ PANGAEA.911365).

The $\mathrm{PIP}_{25}$ indices were calculated by combining $\mathrm{IP}_{25}$ with different phytoplankton markers for semi-quantitative sea ice reconstruction, according to [89]:

$\mathrm{P}_{p} \mathrm{IP}_{25}=\mathrm{IP}_{25} /\left(\mathrm{IP}_{25}+(p \times c)\right)$,

where $p$ is the phytoplankton marker concentration $[p=\mathrm{B}$ (brassicasterol) or D(dinosterol) or III(HBI III)], and c is a balance factor to compensate for a significant concentration difference between $\mathrm{IP}_{25}$ and phytoplankton marker concentration ( $c=$ mean $\mathrm{IP}_{25}$ concentration/mean $p$ concentration). When using HBI III as phytoplankton biomarker and $\mathrm{IP}_{25}$ and HBI III concentrations are similar in magnitude, a balance factor is not needed (i.e., $c=1$ ). The tri-unsaturated HBI ratio "TR 25 " was calculated according to [9]:

$\left[\mathrm{TR}_{25}=\mathrm{Z} /(\mathrm{Z}+\mathrm{E})\right]$.

\section{Results}

\section{Core chronology and sedimentation rates}

The resulting depth-age model ranges between about $10 \mathrm{ka}$ BP and the present (Fig. 2). The sedimentation rates vary between 32 and $172 \mathrm{~cm} \mathrm{ka}^{-1}$. However, mostly high sedimentation rates of $100-150 \mathrm{~cm} \mathrm{ka}^{-1}$ occur throughout the majority of the recovered intervals. A step-wise decrease in sedimentation rates to about $\sim 80 \mathrm{~cm} \mathrm{ka}^{-1}$ (Fig. 2) is observed at about 8-6 ka BP and to about $\sim 30 \mathrm{~cm} \mathrm{ka}^{-1}$ at about 3-1 ka BP, respectively. Excess lead is present down to $4.5 \mathrm{~cm}$ core depth, indicating that the core top is of recent age and only experienced minor disturbance during coring (see inset in Fig. 2). Caesium $\left({ }^{137} \mathrm{Cs}\right.$ ) was discovered in the topmost sample at $0-1 \mathrm{~cm}$ core depth. Accordingly, we assume that the core top is of near-recent age and used an additional tie point of -50 years (i.e., 0 a BP) for the core top. The basal age of the core was determined by extrapolation of the age model beyond the lowermost radiocarbon dating to the core base within $B A C O N$. Consequently, the age model for the lowermost section (1000-1147 cm/>9.4 ka) should be regarded with caution, and thus accumulation rates were not calculated. Further details of the age modeling are given in Table 1 and Fig. 2. Mass accumulation rates ( $\mathrm{g} \mathrm{cm}^{-2} \mathrm{ka}^{-1}$ ) were calculated based on sedimentation rates and dry bulk density data, and were finally used to convert biomarker concentrations into flux rates. 
Fig. 2 Age model for gravity core GeoB19927-3, with rectangles denoting the results of the radiocarbon dating and calibration for one and two $\sigma$-ranges (blue and unfilled boxes, respectively), the red line marking the most likely age and the gray shading indicating the extend of the $95 \%$ confidence interval as determined by BACON [15]. Stippled lines indicate the solely extrapolated age model at the core base. The Inset shows the results of the radionuclide analysis. The sedimentation rate (SR) and accumulation rate (AR) of core GeoB19927-3 are shown versus the age in kilo years before present (ka BP)

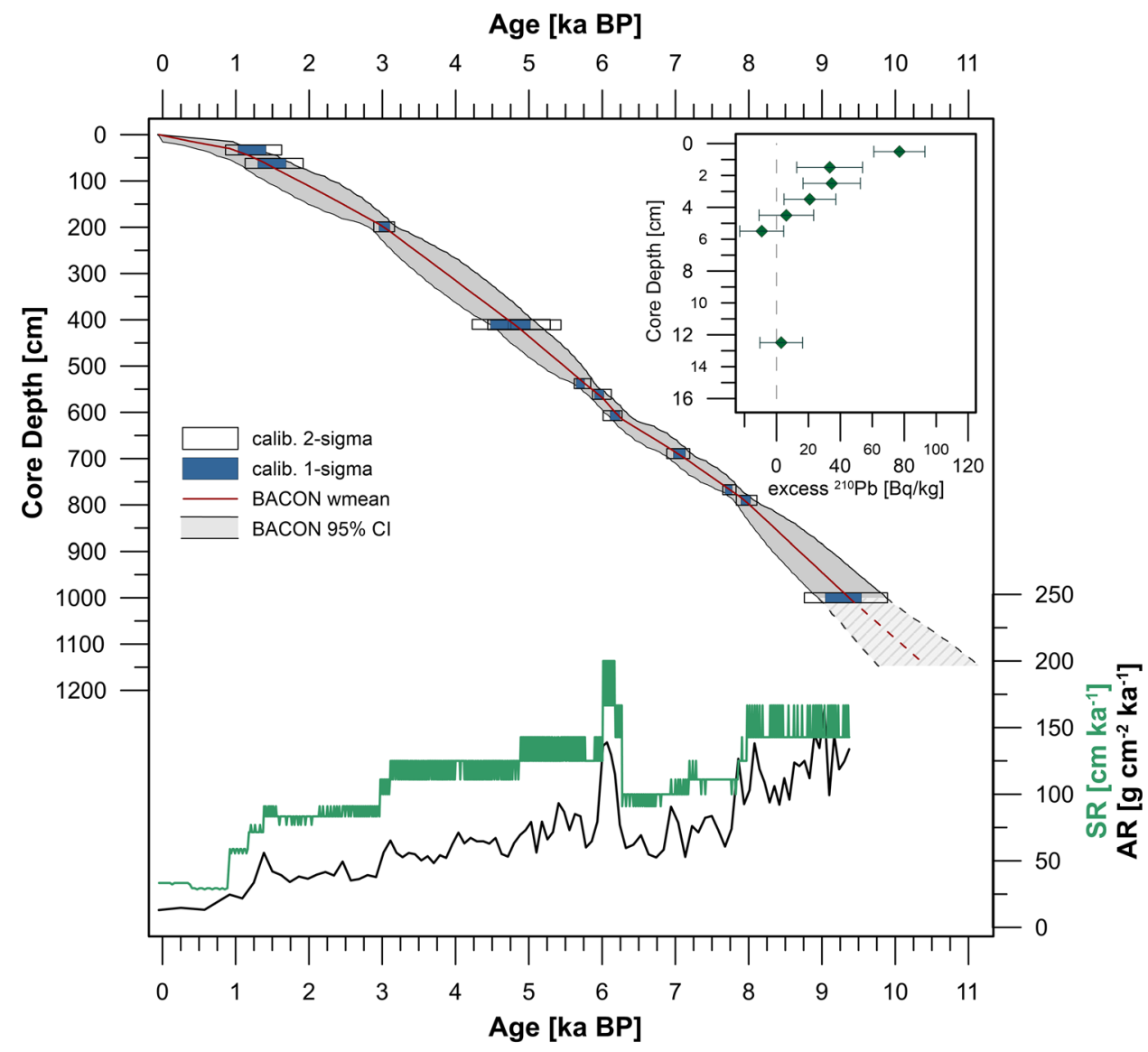

\section{Bulk parameters (sand content and TOC)}

The sand content $(63-2000 \mu \mathrm{m})$ displays high-amplitude changes between 0.5 and $63 \%$ (vol) in the lowermost part of the core (early Holocene), followed by low and stable values of $<2 \%$ in the upper part of the core ( $7.8 \mathrm{ka}$ to present) (Fig. 3a). The TOC contents range from 0 to $1.5 \%$ (Fig. 3b) with minimum but increasing values in the early Holocene (10.4-7.8 ka BP), high values of $>1 \%$ in the mid to late Holocene (7.8 ka to present).

The accumulation rates (or fluxes) of TOC range from 0 to $1.3 \mathrm{~g} \mathrm{~cm}^{-2} \mathrm{ka}^{-1}$ and show distinctly variable but higher values in the early Holocene (9.3-7.8 ka BP), followed by slightly enhanced values of $0.4-1.3 \mathrm{~g} \mathrm{~cm}^{-2} \mathrm{ka}^{-1}$ in the mid Holocene (7.8-3.0 ka BP) with a distinct maximum $\left(\sim 1.3 \mathrm{~g} \mathrm{~cm}^{-2} \mathrm{ka}^{-1}\right)$ at $\sim 6 \mathrm{ka} \mathrm{BP}$ (Fig. 4b). Between 3.0 and $0 \mathrm{ka} \mathrm{BP}$, the TOC flux decreases, reaching a minimum value of $0.16 \mathrm{~g} \mathrm{~cm}^{-2} \mathrm{ka}^{-1}$ at the top of the core.

\section{$\mathrm{IP}_{25}$ and other biomarkers}

$\mathrm{IP}_{25}$ concentrations vary between about 0.5 and $1.5 \mu \mathrm{g} / \mathrm{gTOC}$ in the early Holocene (10.4-7.8 ka BP) with a single distinct maximum of $\sim 3.3 \mu \mathrm{g} / \mathrm{gTOC}$ at $7.9 \mathrm{ka} \mathrm{BP}$, followed by a gradual decrease in the mid Holocene (Fig. 3f). Relatively constant and minimum concentrations of $\mathrm{IP}_{25}(\sim 0.34 \mu \mathrm{g} /$ gTOC) are observed in the late Holocene period (3.0-0 ka BP). The phytoplankton biomarkers brassicasterol and dinosterol show a very similar trend in their concentration record with (sub-) millennial-scale fluctuations ranging from 0 to $30 \mu \mathrm{g} / \mathrm{gTOC}$ and 0 to $37 \mu \mathrm{g} / \mathrm{gTOC}$, respectively (Fig. 3e, d). Intervals of enhanced brassicasterol and dinosterol concentrations are observed from about 9.4 to $8.5 \mathrm{ka} \mathrm{BP}$ of $\sim 30$ and $37 \mu \mathrm{g} / \mathrm{gTOC}$ and from about 7.4 to $6.3 \mathrm{ka} \mathrm{BP}$ of $\sim 19$ and $27 \mu \mathrm{g} / \mathrm{gTOC}$, respectively. In the late Holocene (3.0-0 ka $\mathrm{BP})$, the sterols concentrations are still variable but remain generally low. HBI III concentrations are almost zero before $7.4 \mathrm{ka} \mathrm{BP}$ (Fig. 3c), and remain generally low throughout the mid Holocene (mean $\sim 0.4 \mu \mathrm{g} / \mathrm{gTOC}$ ), except for a prominent peak of $3.6 \mu \mathrm{g} / \mathrm{gTOC}$ at about 7-6.3 ka BP. In the late Holocene, however, HBI III concentrations increase to ca. $0.8 \mu \mathrm{g} /$ gTOC, except for two prominent peaks of 2.7 and $2.0 \mu \mathrm{g} /$ gTOC at about 2.1 and $1.3 \mathrm{ka} \mathrm{BP}$, respectively.

$\mathrm{IP}_{25}$ fluxes range from 0 to $1.65 \mu \mathrm{g} \mathrm{cm}^{-2} \mathrm{ka}^{-1}$ and areexcept for the lowermost part-relatively high in the early Holocene, reaching maximum values at 8.6-8.4 ka BP. In the mid Holocene, the $\mathrm{IP}_{25}$ fluxes decrease until $3 \mathrm{ka} \mathrm{BP}$, with some peaks of 1.0, 0.8, 0.9, and $0.4 \mu \mathrm{g} \mathrm{cm}^{-2} \mathrm{ka}^{-1}$ at about 


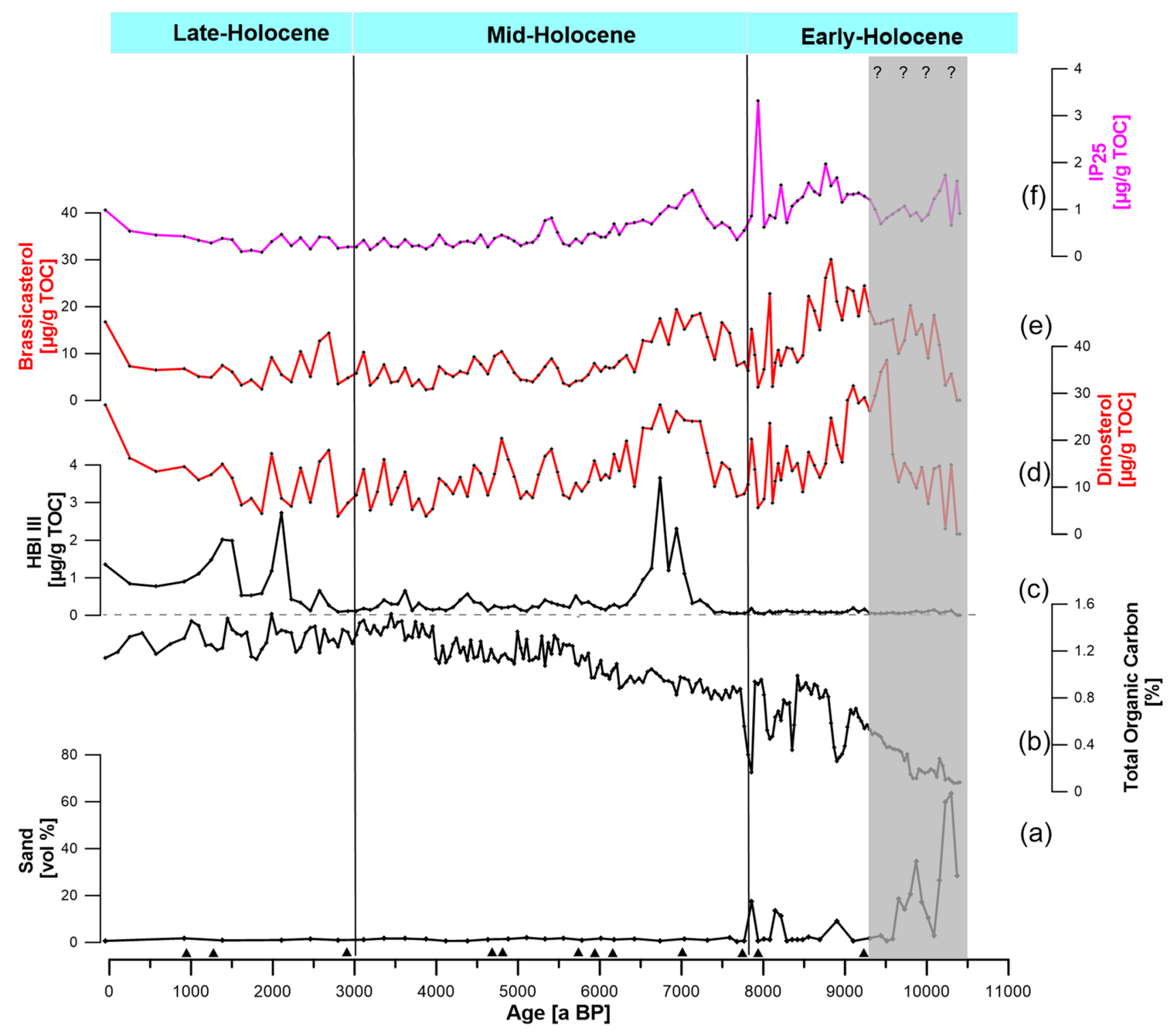

Fig. 3 Combined record of bulk parameters and biomarkers of core GeoB19927-3 a Sand content (vol \%), b Total organic carbon (TOC) content (\%), c HBI III ( $\mu \mathrm{g} \mathrm{g}^{-1}$ TOC), d dinosterol ( $\mu \mathrm{g} \mathrm{g}^{-1}$ TOC), e

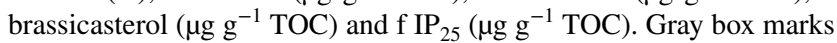

7, 6.1, 5.4, and 4.5 ka BP, respectively (Fig. 4f). Minimum $\mathrm{IP}_{25}$ flux rates of about $0.14 \mu \mathrm{g} \mathrm{cm}^{-2} \mathrm{ka}^{-1}$ are observed in the late Holocene. Flux rates of brassicasterol (Fig. 4e) vary between 0 and $23 \mu \mathrm{g} \mathrm{cm}^{-2} \mathrm{ka}^{-1}$ with the absolute maximum at $\sim 9.3-8.6 \mathrm{ka}$. While, flux rates of dinosterol vary between 0 and $19 \mu \mathrm{g} \mathrm{cm}^{-2} \mathrm{ka}^{-1}$, and attain a maximum of about $19 \mu \mathrm{g} \mathrm{cm}^{-2} \mathrm{ka}^{-1}$ at $\sim 6.1 \mathrm{ka} \mathrm{BP}$ (Fig. 4d). During the mid Holocene, brassicasterol and dinosterol fluxes show a cyclic variability with a decrease in maximum values towards the top. During the last $3 \mathrm{ka} \mathrm{BP}$, minimum fluxes of brassicasterol and dinosterol between 1.1 and 6.8, and 1.9 and $4.9 \mu \mathrm{g} \mathrm{cm}^{-2} \mathrm{ka}^{-1}$, respectively, are typical. In general, the the lower-most section of core, where the age model is extrapolated, and data have to be interpreted with caution. All plots are shown versus age in years before present (a BP). Black solid triangles mark the AMS ${ }^{14} \mathrm{C}$-datings

HBI III fluxes display a similar pattern to its concentration record throughout the core (Fig. 4c). Low HBI III fluxes of $<0.1$ and between 0.1 and $0.4 \mu \mathrm{g} \mathrm{cm}^{-2} \mathrm{ka}^{-1}$ occur in the oldest part $>7.5$ and between 6.4 and $2.4 \mathrm{ka} \mathrm{BP}$, respectively. Prominent maxima of 1.96, 1.54, and $1.21 \mu \mathrm{g} \mathrm{cm} \mathrm{ka}^{-1}$ are recorded at 7.0-6.3, 2.0, and $1.4 \mathrm{ka} \mathrm{BP}$, respectively. Both $\mathrm{P}_{\mathrm{B}} \mathrm{IP}_{25}$ and $\mathrm{P}_{\mathrm{D}} \mathrm{IP}_{25}$ indices are intermediate to high, varying in the range between 0.3 and 1 ; whereas $\mathrm{P}_{\mathrm{III}} \mathrm{P}_{25}$ index remained high $(\sim 0.9)$ in the early Holocene (Fig. 5a). In the mid to late Holocene, $\mathrm{P}_{\mathrm{B}} \mathrm{IP} 25, \mathrm{P}_{\mathrm{D}} \mathrm{IP} 25$ and $\mathrm{P}_{\mathrm{III}} \mathrm{IP}_{25}$ indices display cyclic variability with minima at 7.0-6.3, 5.8-5.5, 4.5-4.2, 3.7-3.2 and $2.1-1.3$ ka BP (Fig. 5a; 


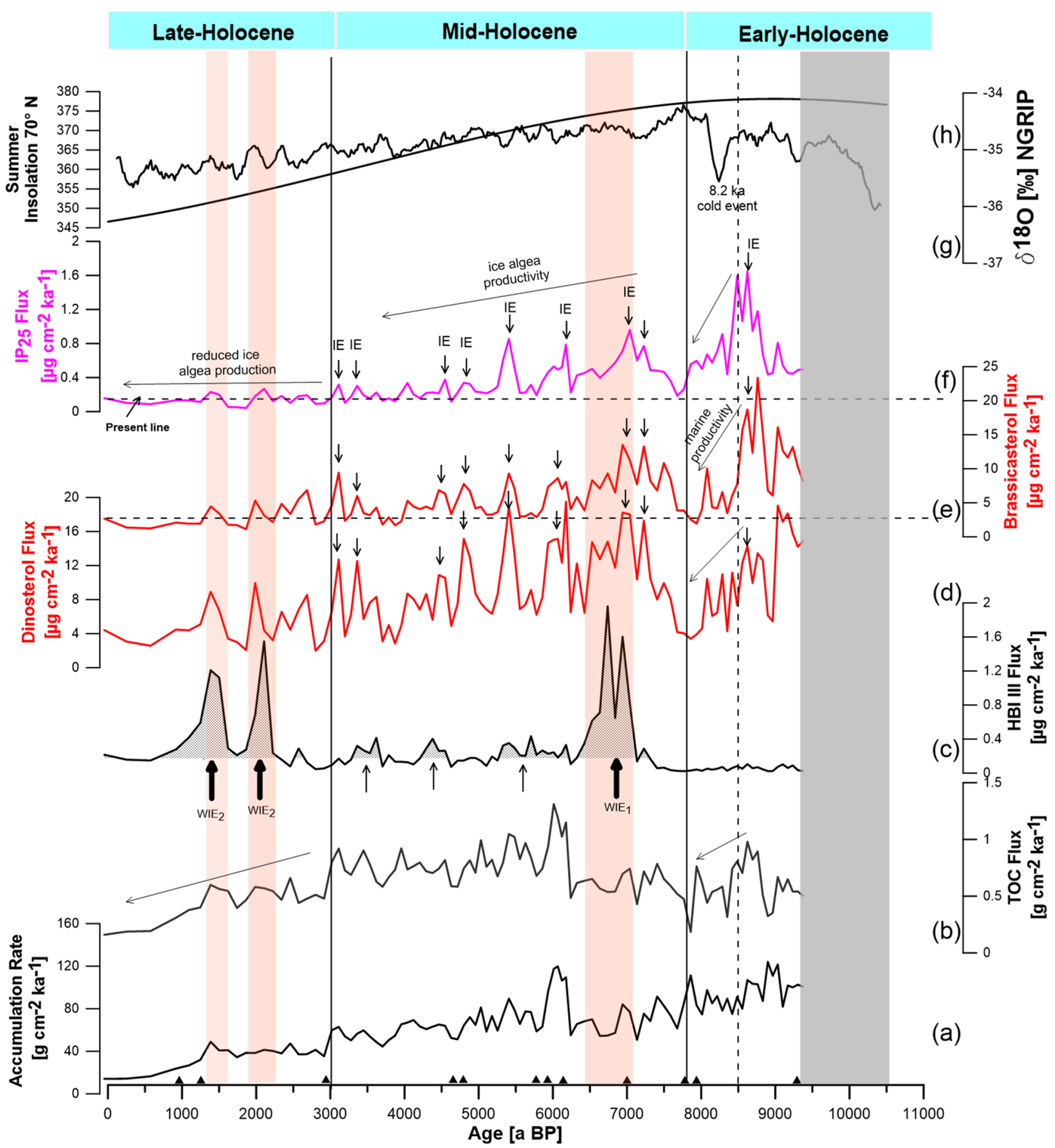

Fig. 4 a Bulk accumulation rate and accumulation (flux) rates of (b) total organic carbon (TOC) $\left(\mathrm{g} \mathrm{cm}^{-2} \mathrm{ka}^{-1}\right)$, c HBI III $\left(\mu \mathrm{cm}^{-2} \mathrm{ka}^{-1}\right)$, d dinosterol $\left(\mu \mathrm{g} \mathrm{cm}^{-2} \mathrm{ka}^{-1}\right)$, e brassicasterol $\left(\mu \mathrm{g} \mathrm{cm}^{-2} \mathrm{ka}^{-1}\right)$, f sea ice proxy $\mathrm{IP}_{25}\left(\mu \mathrm{g} \mathrm{cm}^{-2} \mathrm{ka}^{-1}\right), \mathrm{g}^{18} \mathrm{O}$ record of the NGRIP ice core from Greenland [124], h Summer insolation at $70^{\circ} \mathrm{N}$ [68]. All plots are shown versus age in years before present $(\mathrm{a} B \mathrm{BP}) . \mathrm{WIE}_{1}$ and $\mathrm{WIE}_{2}$ shown as orange bars, are interpreted as (late) winter-ice-edge (WIE) situations. (cf., [12] and discussion for further explanation). Simultaneous peaks in $\mathrm{IP}_{25}$ and phytoplankton; brassicasterol and dinosterol, shown as black downward arrows, are interpreted as (polynya-type) reoccurring ice-edge (IE) situations. Gray box marks the core base where the age model is extrapolated and interpreted with caution. Thus, accumulation rates were not calculated. Black solid triangles mark the AMS ${ }^{14} \mathrm{C}$-datings 


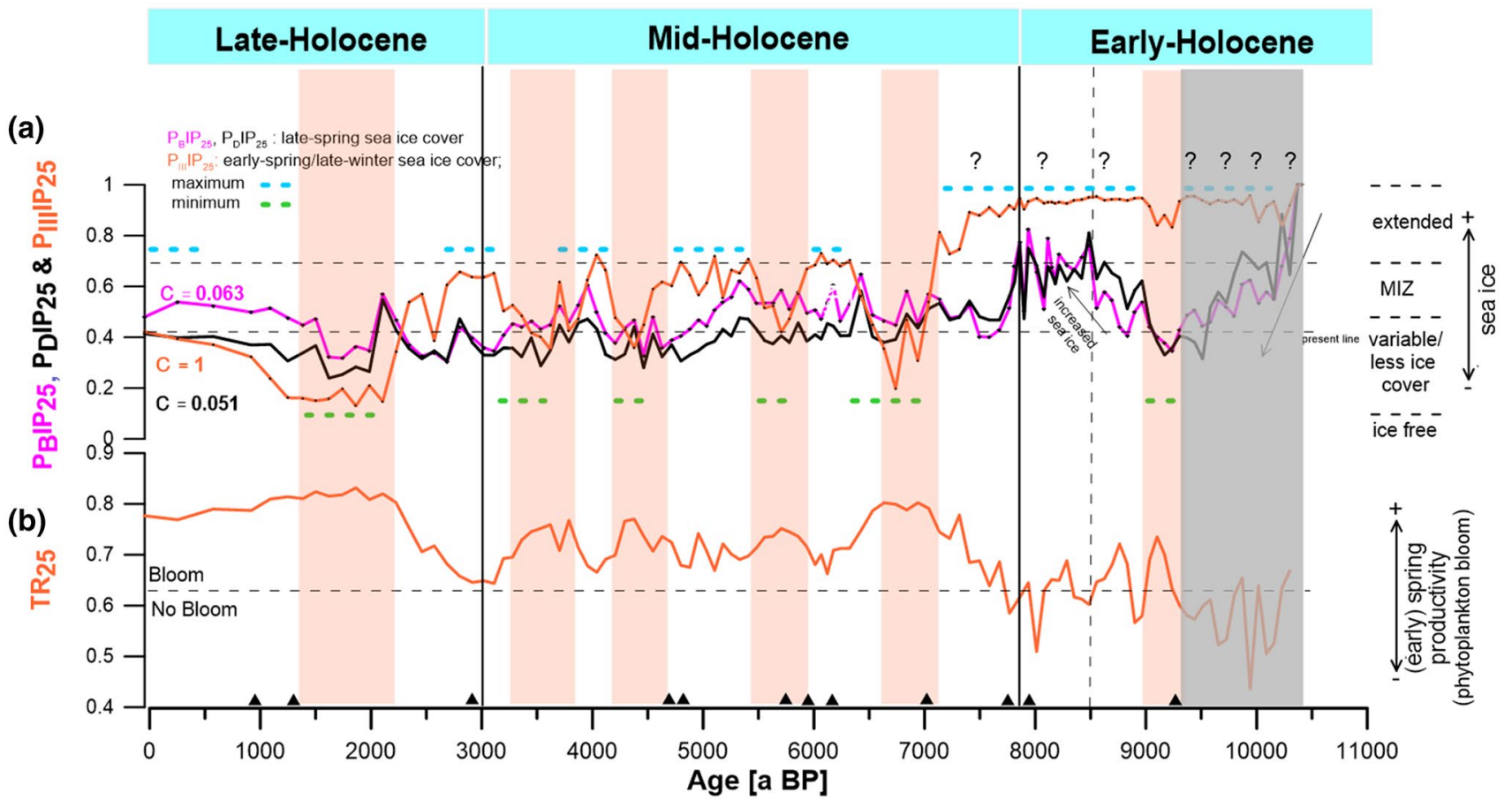

Fig. 5 a $\mathrm{PIP}_{25}$ indices using brassicasterol $\left(\mathrm{P}_{\mathrm{B}} \mathrm{IP}_{25}\right)$, dinosterol $\left(\mathrm{P}_{\mathrm{D}} \mathrm{IP}_{25}\right)$, and HBI III $\left(\mathrm{P}_{\mathrm{III}} \mathrm{IP}_{25}\right)$. $\mathrm{P}_{\mathrm{III}} \mathrm{IP}_{25}$ cyclicity with minimum values marked as orange bars, probably represents different marginal ice zone (MIZ) situations. Classification of different sea ice scenarios based on Müller et al. [89]. b HBI $\mathrm{TR}_{25}$ as a potential proxy for

green dots). HBI $\mathrm{TR}_{25}$ ratio (Fig. $5 \mathrm{~b}$ ) is highly variable and ranges from $\sim 0.5$ to 0.8 . The ratio is generally low $(\sim 0.6)$ in the early Holocene, except for peaks of about 0.7 at $~ 9.1$ and $\sim 8.7 \mathrm{ka} \mathrm{BP}$. In the mid to late Holocene, it displays cyclic variability and maxima $(>0.7)$ at 7.1-6.6, 5.9-5.4, 4.6-4.2, 3.8-3.2, and 2.2-1.3 ka BP, coinciding with minima in $\mathrm{P}_{\mathrm{III}} \mathrm{IP}_{25}$ index (Fig. 5b; orange bars). In the last $2.3 \mathrm{ka}$ $\mathrm{BP}$, however, $\mathrm{TR}_{25}$ displays the highest concentrations with values of $\sim 0.8$.

\section{Discussion}

The biomarker approach presented here allows a comprehensive investigation of paleoceanographic changes in $\mathrm{NE}$ Baffin Bay, including variations in sea ice cover, primary production and in combination with other proxies-the variability in strengths of oceanic currents (i.e., WGC, BC, etc.) with a ca 100-year time resolution during the Holocene. The Holocene is characterized by significant changes in oceanic forcing as well as Northern Hemisphere solar insolation [68] and, as a result, affecting the advance and retreat of sea ice cover and ice sheets in the region. Furthermore, the combined use of the different PIP $_{25}$ approaches allowed to distinguish between different seasonal ice-edge situations (cf., (early) spring productivity and/or phytoplankton bloom (cf., [9]). The dotted line $\sim 0.62$ distinguishing between bloom/no bloom is based on the binary threshold model proposed by [9]. Gray box marks the core base where the age model is extrapolated, and data have to be interpreted with caution. Black solid triangles mark the AMS ${ }^{14} \mathrm{C}$-datings

$[12,89]$, see "Biomarker proxies for paleo-environmental reconstruction"). Notably, the phytoplankton biomarkers brassicasterol and dinosterol from our records show a high correlation $\left(R^{2}=0.8\right)$ suggesting co-production of these sterols in a similar open marine environment. This is also reflected in similar trends in their $\mathrm{P}_{\mathrm{B}} \mathrm{IP}_{25}$ and $\mathrm{P}_{\mathrm{D}} \mathrm{IP}_{25}$ indices (Fig. 5a). Our combined proxy record based on sea ice $\left(\mathrm{IP}_{25}\right)$, phytoplankton biomarkers (brassicasterol, dinosterol, and HBI III) and bulk parameters indicate a consistent presence of seasonal sea ice (Figs. 3, 6) during the Holocene, although the extent and duration of ice cover situation have changed throughout the Holocene.

\section{Sea ice variations in the NE Baffin Bay during the Holocene}

\section{Early Holocene}

From final deglacial cold phase to early Holocene warming between $~ 10.4$ (?) and 8.5 ka BP In the lower-most period (1147-1070 cm / > 9.4 ka; see Supplementary Fig. S1), minimum values to the absence of ice algae biomarkers, phytoplankton biomarkers, TOC and $\mathrm{TR}_{25}$ but high $\mathrm{P}_{\mathrm{III}} \mathrm{IP}_{25}(\sim 0.9)$ index (Figs. 3,5 ) indicate colder conditions with extensive sea ice cover during most part of the year except very short 


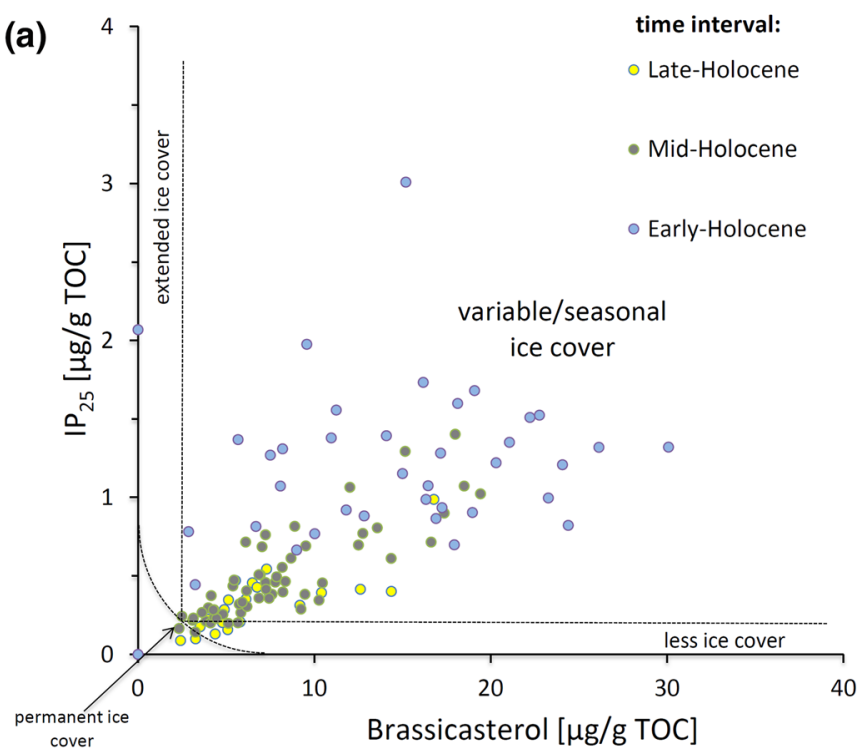

Fig. 6 a $X-Y$ plot of $\mathrm{IP}_{25}$ vs. brassicasterol, indicating variable seasonal to ice-edge conditions, according to Müller et al. [89]. Time intervals and different symbols are explained in the legend. b $X-Y$ plot of $\mathrm{IP}_{25}$ vs. HBI III. There is no clear correlation of $\mathrm{IP}_{25}$ with HBI III; however, unusually elevated values of HBI III compared to (low)

seasonal break-up periods during late spring and/or autumn $\left(\mathrm{P}_{\mathrm{B}} \mathrm{IP}_{25} \sim 0.6\right)$, coinciding with high ice-rafted debris (IRD) values (indicated by high sand content; Fig. 3a). The high amount of terrigenous material (indicated by high IRD) entrapped during sea ice formation in winter and released nutrients in late spring may have facilitated some primary production (Fig. 3d, e) [106]. The colder conditions in Baffin Bay could also be due to the presence of active ice streams [1,32] and strongly stratified conditions, possibly related to glacial outwash events and melt-water influx from the retreating ice, and a limited strength of the WGC [52, 70, 101].

Following this initial period, the interval $\sim 9.4-8.5 \mathrm{ka}$ BP $(1070-890 \mathrm{~cm})$ is marked by pronounced peaks in the fluxes of $\mathrm{IP}_{25}$, phytoplankton biomarkers brassicasterol and dinosterol and TOC as well as $\mathrm{TR}_{25}$ (Figs. 4, 5), pointing all towards rapid changes in the area characterized by variable/less sea ice to ice-edge (MIZ) conditions and high in situ productivity (Fig. 5a). This reduction in sea ice and increased marine productivity might point towards warmer surface conditions in the early Holocene, marked by strong atmospheric forcing (Fig. 7i). Low values of $\mathrm{P}_{\mathrm{B}} \mathrm{IP}_{25}$ and $\mathrm{P}_{\mathrm{D}} \mathrm{IP}_{25}$ indices, coinciding with low IRD (Figs. 3a, 5a), may reflect a retreat in sea ice cover (and glaciers) and indicate a phase of more open-water conditions in late spring and/ or autumn. Based on the $\mathrm{P}_{\mathrm{III}} \mathrm{IP}_{25}$ values, high sea ice cover might have persisted until early-springs seasons (Fig. 5a). These numbers, however, have to be interpreted very cautiously due to the extremely low HBI III values.

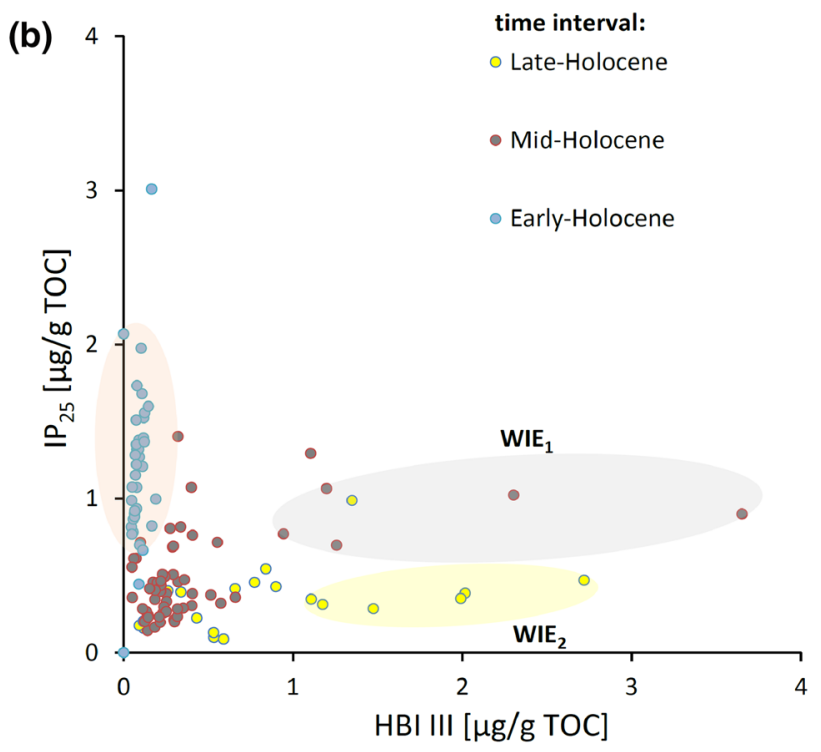

$\mathrm{IP}_{25}$ and vice versa are shown in colored ellipses marked as $\mathrm{WIE}_{1}$ and $\mathrm{WIE}_{2}$, interpreted as (late) winter-ice-edge (WIE) situations and longer (spring) sea ice seasons, respectively (cf. [12] and discussion for further explanation)

We think this is linked to the northward penetration of the WGC, transporting warm Atlantic Water along the West Greenland coast since at least 10.4-9 ka BP [41, 52] and, thus, causing higher sea-surface temperatures in northern Baffin Bay. Knudsen et al. [59] reported an increase in calcareous benthic foraminiferal flux and heavier $\delta^{18} \mathrm{O}_{\text {benthic }}$ values through this interval supporting the influence of WGC up to the northern Baffin Bay and subsequently more open surface waters and reduced sea ice coverage. Based on bowhead bone remains [34], $\mathrm{IP}_{25}$ record from the Canadian Arctic Archipelago Vare et al. [122], and ice-edge indicator foraminifera species (S. feylingi) from Upernavik area Hansen et al. [41], the authors reported reduced to ice-edge sea ice cover, similar to our findings in this study. Based on foraminifera, Ostermann and Nelson [95] reported a similar influx of relatively warm, high saline water into the north of Baffin Bay between $~ 9.8$ and 8.5 ka BP. Furthermore, Levac et al. [71] reported an increase in dinoflagellate abundances from a sediment core in the northern Baffin Bay, suggesting similar warming of surface waters.

The interpretation of continued strong melting with warmer summer waters in Baffin Bay corresponds to the significant climate warming in the early Holocene, widely recognized in the Northern Hemisphere [56, 123]. These warm conditions might have led to high sedimentation rates as a result of increased marine productivity, ice melting, and glacially derived material from adjacent ice sheets in NE Baffin Bay [21, 41]. This is in agreement with high accumulation rates and relatively high terrigenous detritus (Figs. 2, 


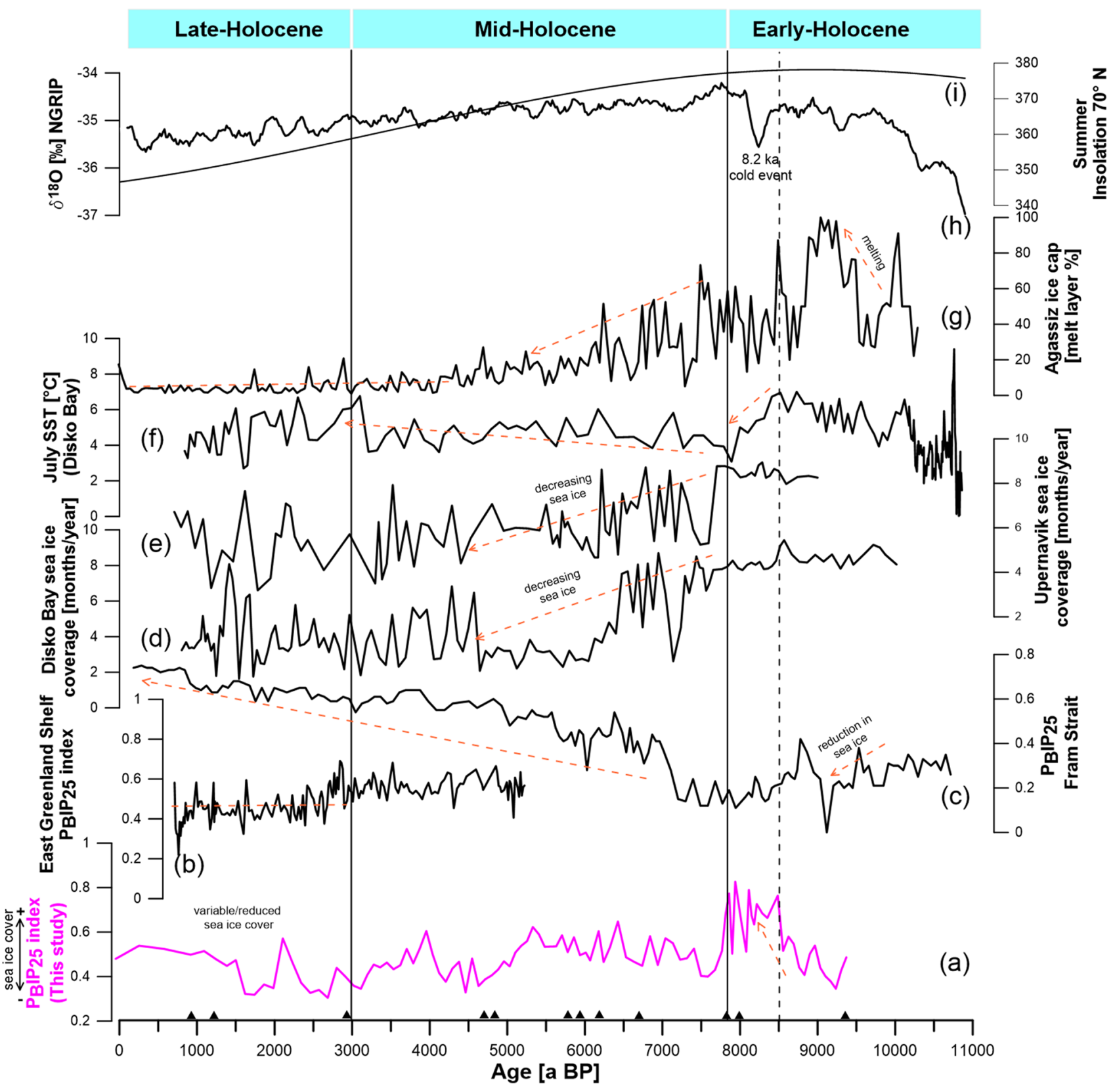

Fig. 7 Comparison of different environmental proxy records around and from Greenland. a $\mathrm{P}_{\mathrm{B}} \mathrm{IP}_{25}$ record from the Melville Bugt (Core GeoB19927-3, this study), b $\mathrm{P}_{\mathrm{B}} \mathrm{IP}_{25}$ record from East Greenland Shelf (Core PS2641; [60]), c Fram Strait (Core MSM5/5-712-2; [88]), d dinocyst-based sea ice cover reconstruction (months of sea ice/year) from Disko Bay (Core MSM343300; [96]), e dinocyst-based sea ice

3a) recorded in the sediments in this interval, which may indicate a strong melt-water input associated with melting of sea ice, GIS and nearby glaciers such as Ussing Braeer and Cornell glacier located near Melville Bugt $[54,56]$. Notably, the period with maximum dinosterol flux (Fig. 4d) and spring ice melting in Baffin Bay coincides with maximum Agassiz Ice Cap melt percent ( 9.4-8.5 ka BP) [37] cover reconstruction (months of sea ice/year) from Upernavik (Core AMD14-204C; [22]), f diatom-based SST reconstruction from West Greenland (Core MSM343300; [64]), g the Agassiz Melt Layer Record [37], h the $\delta^{18} \mathrm{O}$ record of the NGRIP ice core from Greenland [124] and $i$ the summer insolation at $70^{\circ} \mathrm{N}$ [68]. Black solid triangles mark the AMS ${ }^{14} \mathrm{C}$-datings

and maximum summer insolation at $70^{\circ} \mathrm{N}$ or higher latitudes ([68] (Fig. 7g, i), which suggests significant warm conditions and increased marine productivity in the area. Ice retreat velocity data $\left(\sim 4.8 \mathrm{~km} \mathrm{a}^{-1}\right)$ from Jakobshavns Isbrae also indicate similar rapid deglacial melting following increased atmospheric temperatures at about 9.4-8.5 ka BP ( $[80,124]$. Additionally, the increase in the amount 
of pollen grains from Ellesmere Island could also indicate the maximum summer melting between $\sim 9.8$ and $8.5 \mathrm{ka} \mathrm{BP}$ $[17,66]$. This characteristic warming, reduction of spring/ summer sea ice and deglacial melting of the GIS have been widely reported in the areas such as Fram Strait and Disko Bay based on PIP $_{25}$ (Fig. 7c) and SST record (Fig. 7e) [64, 88, 132].

\section{Extended sea ice cover and opening of connection} to the Arctic between $\sim 8.5$ and 7.8 ka BP Despite the high solar insolation and deglacial melting having culminated, environmental conditions in northern Baffin Bay remained cold and unstable between $\sim 8.5$ and $~ 7.8 \mathrm{ka}$ BP [35] likely due to counter-effect of the Laurentide, Greenland and Innuitian ice sheets and a connection to the Arctic Ocean [59]. A distinct decrease in ice algae and phytoplankton productivity (Fig. $4 \mathrm{~d}-\mathrm{f}$ ), coinciding with peaks in IRD (Fig. 3a) during this interval, indicates a period of major environmental change in the area. Cold surface water conditions and increased, partly almost closed sea ice cover in this period are indicated by the $\mathrm{P}_{\mathrm{B}} \mathrm{IP}_{25}, \mathrm{P}_{\mathrm{D}} \mathrm{IP}_{25}$, and $\mathrm{P}_{\mathrm{III}} \mathrm{IP}_{25}$ indices, increasing to a maximum of $0.8-0.9$ (Fig. 5a). Our biomarker records point to an interval of extended sea ice and major changes in Baffin Bay that might be related to the opening towards the Arctic Ocean via Nares Strait as proposed in several studies: based on sedimentological and geological data. Jennings et al. [48, 52] and Georgiadis et al. [39] suggested that Nares Strait opened at $~ 9-8.3 \mathrm{ka}$ BP. Although, given the uncertainties in $\Delta \mathrm{R}$ values, the timing of the exact opening of the strait is still subject to debate [52].

In the period between 8.5 and $7.8 \mathrm{ka} \mathrm{BP}$, our interpretation of extended ice cover throughout the year, except during a short summer season and colder conditions and declined marine productivity, is in accordance with the previously reported increase in assemblages of cold water foraminifera and diatoms in Baffin Bay [51, 75, 85]. Similarly, Knudsen et al. [59] and Ouellet-Bernier et al. [96] reported an increase in the abundance of large-sized diatoms after $\sim 8.2 \mathrm{ka} \mathrm{BP}$, related to Polar Water influx from the Arctic Ocean, and the opening of Nares Strait [49]. Furthermore, based on higher abundances of the Arctic water foraminifera (I. norcrossi) $[41,85]$ and a distinct maximum of dinocyst assemblages (Fig. 7d, e) at $\sim 8.3 \mathrm{ka} \mathrm{BP}[22,96]$ (Fig. 7d, e), the authors describe an interval of dense sea ice cover ( $>9$ months year ${ }^{-1}$ ) and cold sub-surface water inflow (core MSM343300, AMD14-204C; Fig. 1a, b) in Baffin Bay; whereas GIS was probably retreating. The cold event coincided with the final phase of deglaciation of the IISs and LISs $[33,46]$ and might also be concurrent with the widely reported $\sim 8.2$ ka cold event in the Northern Hemisphere [3, $47,82,91]$. A decrease in the number of melt layers from the Agassiz Ice Cap shows a temperature decrease between
8.5 and $7.8 \mathrm{ka} \mathrm{BP}$ and thus colder conditions [124] (Fig. 7g). Similarly, Jennings et al. [47] also observed episodic cooling of the Irminger Current (that feeds the WGC) resulting from the last phases of the waning LIS. Either or a combination of these scenarios could be responsible for cold fresh-water input into Baffin Bay, resulting in increased sea ice cover and colder conditions in the area.

\section{Mid Holocene}

A cyclic change of minima and maxima in sea ice cover is evident after $7.8 \mathrm{ka} \mathrm{BP}$, as shown by $\mathrm{PIP}_{25}$ index cyclicity (Fig. 5a). Furthermore, contemporaneous peaks in accumulation rates of $\mathrm{IP}_{25}$ and the phytoplankton biomarkers brassicasterol and dinosterol (Fig. 4d-f) display reoccurring spring ice-edge conditions. This may be related to oscillations in the strengths of the WGC and the melting of sea ice [22, 59, 96]. Interestingly, the HBI III record shows a pronounced maximum between 6.3 and $7.0 \mathrm{ka} \mathrm{BP}$, followed by three smaller peaks of elevated HBI III values at 5.7-5.2, 4.5-4.3, and 3.6-3.3 ka BP (Fig. 4c). According to Belt et al. [12], such HBI III maxima may indicate increased phytoplankton productivity and winter-ice-edge limit (Fig. 6b). Baffin Bay is strongly influenced by seasonal melt-water inflow from the GIS, wind favored deep upwelling and light availability, which may, in turn, also influence the production of HBI III $[11,44]$. The strong seasonality in this area may explain such an elevated occurrence of HBI III in ice-edge scenarios. Peaks in HBI III associated with enhanced growth of phytoplanktons near MIZ, may also indicate an up-welling situation (i.e., sites near polynya settings; NWP) caused by wind favored mixing in the late-winter months, when northwesterly wind stress is stronger [26, 59, 71, 84, 86, 119]. The $\mathrm{P}_{\mathrm{III}} \mathrm{IP}_{25}$ indices display minima at 7.0-6.3, 5.8-5.5, 4.5-4.2, and 3.7-3.2 ka BP, coinciding with maxima in the $\mathrm{TR}_{25}$ record, which may be interpreted as ice-edge (polynyatype) situation with reduced sea ice cover and elevated primary production during late winter/early spring (Fig. 5b). The intervals in between are characterized by more extended late winter/early spring sea ice conditions.

A number of paleoclimatic records from the Canadian Arctic islands, the Baffin Bay, and offshore Greenland, support the reconstruction of sea surface conditions presented herein. The northward retreat of ice sheets, further from the coastline, may have led to reduced melt-water supply [22, 41] and further establishment of rather stable oceanographic conditions. Widespread presence of mollusks and Atlantic water indicator species, i.e., P. bipolaris, as well as increased organic carbon accumulation beginning at $~ 7.9-7.5 \mathrm{ka} \mathrm{BP}$ offshore NW Greenland, supports the dominant influence of the WGC in the region $([41,101,107]$. Several records from circum-Greenland, the Canadian Arctic Archipelago, the Barents Sea, Iceland, and Svalbard shelves reported the similar 
strengthening of WGC and Irminger Current since $7.8 \mathrm{ka}$ BP $[4,34,47,51,55,77,96]$. Furthermore, between $~ 7.3$ and $\sim 6.2 \mathrm{ka} \mathrm{BP}$, a reduced sea ice cover and relatively warm WGC were recorded at several sites, including northern Baffin Bay and the eastern Labrador Sea [30, 97]. Thomas et al. [120] have shown a major increase in winter snowfall during mid Holocene caused by reduced sea ice and open surface water conditions in Baffin Bay and the Labrador Sea, consistent with the occurrence of polynya-type (winter) ice-edge variability. Slightly less pronounced, but warming trend is also observed from the Disko Bay area, based on diatomsbased SST data (Fig. 7f) [64]. Many marine and terrestrial records have also reported the GIS retreat from Disko Bay during this time interval $[77,79,115]$, in agreement with our reconstructions in NE Baffin Bay.

\section{Late Holocene}

During the last $3 \mathrm{ka} \mathrm{BP}$, the concentrations and accumulation rates of $\mathrm{IP}_{25}$, marine sterols (Figs. 3, 4d-f), and related $\mathrm{PIP}_{25}$ index values remain relatively low and do not reflect the Late Holocene 'Neoglacial' cooling trend that follows the decreasing insolation pattern [68] (Fig. 7a, i), widely observed in Northern Hemisphere, such as in eastern Baffin Bay, the Fram Strait and the Canadian Arctic Archipelago area (Fig. 7d, f) [41, 64, 89, 96, 129]. This difference might be due to the dominance of the WGC along the West Greenland coast and sea ice interactions with the adjacent fjord, which may further mitigate sea ice growth. Furthermore, our $\mathrm{PIP}_{25}$ indices show relatively moderate values $(0.2-0.6)$, suggesting a reduced sea ice cover, especially between about 2.4 and $1.0 \mathrm{ka} \mathrm{BP}$ (Fig. 5a). Sea ice might have only occurred during the late winter/early spring of this time span, as shown by minimum $\mathrm{P}_{\mathrm{III}} \mathrm{IP}_{25}$ values and the $\mathrm{HBI}$ III maxima (Figs. 4c, 5a). Notably, the pronounced peaks in HBI III flux and $\mathrm{TR}_{25}$ (Fig. 5b) at about 2.1 and $1.3 \mathrm{ka} \mathrm{BP}$ that might coincide with the Roman Warm Period (RWP) and Medieval Climate Anomaly (MCA), respectively, can be associated with stronger WGC pulses. As our core site is not too distant from NWP, a polynya-type, marginal ice zone situation, driven by northerly winds and occasional upwelling during the warm periods is another option to explain increased productivity and related elevated HBI III values. Similarly, Knudsen et al. [59] reported an increase in large diatoms between 2 and $0.6 \mathrm{ka} \mathrm{BP}$, interpreted as warmer conditions and high productivity in Disko Bay. Based on foraminiferal and sedimentological proxies from West Greenland, Lloyd et al. [78] and Norgaard-Pedersen and Mikkelsen [93] also observed relatively warm oceanic conditions at $\sim 2-1.4 \mathrm{ka}$ BP. Furthermore, based on benthic foraminifera analysis, Perner et al. [97] described a period of warming from $\sim 1.4$ to $0.9 \mathrm{ka} \mathrm{BP}$ and a relatively warm phase at $\sim 1.8 \mathrm{ka}$ BP and suggested an increased IC contribution to the WGC during the RWP and MCA. Perner et al. [97], Kolling et al. [60] and Allan et al. [2] suggested an enhanced Atlantic Water inflow to the WGC and reduced (winter-only) sea ice between $\sim 1.4-0.9 \mathrm{ka}$ BP and $\sim 1.8 \mathrm{ka} \mathrm{BP}$, with beneficial conditions for phytoplankton blooms, in agreement with our findings.

Several studies have recognized a complex feedback system between Arctic sea ice and the North Atlantic Oscillation (NAO) and reported an anti-phase correlation to the NAO mode associated with the RWP and MCA [63, 67, 99, 108]. However, our records point towards an in-phase response of sea ice cover with changes in NAO modes (i.e., warming during the positive NAO mode associated with the RWP and MCA [74, 121]. However, it should be noted that NAO reconstructions are still subject to debate and far from being fully understood (cf., $[62,108]$ for a detailed discussion).

Based on an $\mathrm{IP}_{25}$ record from the East Greenland shelf (Fig. 7b), Kolling et al. [60] reported that the $\mathrm{PIP}_{25}$ index therein also does not reflect the 'Neoglacial' cooling trend, similar to the records of our study. Based on diatom and foraminifera assemblages, Moros et al. [85] and Caron et al. [22] (Fig. 7e) suggested warm, stratified and highly productive waters in Baffin Bay area [83, 104], in agreement with our interpretation. Glaciers, land-fast ice, and local fjords may also have a more direct and unfavorable influence on the growth of sea ice cover [103].

\section{Summary and conclusions}

Holocene sea ice conditions and marine phytoplankton productivity were reconstructed to gain direct insights into the sea ice variability and its driving mechanisms using a multi-proxy biomarker approach. Organic geochemical and biomarker analyses of a well ${ }^{14} \mathrm{C}$-AMS- and ${ }^{210} \mathrm{~Pb}$-dated sediment core from NE Baffin Bay show that major environmental and paleoceanographic changes occurred in this area.

In the lower-most part, a cold interval characterized by extensive sea ice cover and very low local productivity is succeeded by an interval ( 9.4-8.5 ka BP) of persistent, albeit strongly variable (reduced) sea ice cover, enhanced GIS spring melting, and strong influence of the WGC in the earliest part of the record. A short-term cooling event is recorded by the ice algae and phytoplankton biomarkers between 8.5 and $7.8 \mathrm{ka} \mathrm{BP}$, pointing towards an increased seasonal sea ice cover as a result of the opening of Nares Strait which led to an increased influx of Polar Water into the Baffin Bay, albeit insolation remained generally high.

The interval between 7.8 and $3.0 \mathrm{ka} \mathrm{BP}$ is characterized by reduced sea ice with millennial-scale variability of (late winter) ice-edge limit and WGC strength, and increased open-water (polynya-type) conditions correspond to 'warmer' conditions. 
Our $\mathrm{IP}_{25}$-based sea ice reconstructions and related $\mathrm{PIP}_{25}$ index do not reflect the late Holocene Neoglacial cooling trend during the last $3 \mathrm{ka} \mathrm{BP}$, probably due to the strong influence of the WGC and interactions with the adjacent fjords. Peaks in HBI III at about 2.1 and $1.3 \mathrm{ka} \mathrm{BP}$ might coincide with the RWP and MCA, respectively, and are associated with an enhanced WGC and in-phase correlation with NAO mode.

The result of this multi-proxy approach presented here seems to display the rapid transitions between different climate events and indicate a close connection of sea ice variations in the Northern Hemisphere driven by the interplay between melt-water discharge and solar and oceanic forcings (i.e., WGC, BC). These findings may help to understand the recent reduction in sea ice cover and further improve our climate models and climate predictions. More high-resolution studies are needed to understand the complex interaction of sea ice, its driving mechanisms, and fjord interactions in Baffin Bay.

Acknowledgements Open Access funding provided by Projekt DEAL. We like to thank the captain, the crew of R/V Maria S. Merian MSM44, and the science party, for their excellent work. We are thankful to Walter Luttmar and Susanti Wirda for their technical support. We are very thankful to Gesine Mollenhauer for high-precision analyses of small-scale ${ }^{14} \mathrm{C}$ samples with the AWI MICADAS facility. We would like to thank the editor and three anonymous reviewers who provided numerous helpful suggestions to improve the manuscript. The financial support by the Deutsche Forschungsgemeinschaft through 'ArcTrain' (GRK 1904) is gratefully acknowledged. We acknowledge support by the Open Access Publication Funds of Alfred-Wegener-Institute Helmholtz-Zentrum für Polar- und Meeresforschung. All data used in this work can be found online at https://doi.pangaea.de/10.1594/ PANGAEA.911365.

\section{Compliance with ethical standards}

Conflict of interest On behalf of all authors, the corresponding author states that there is no conflict of interest.

Open Access This article is licensed under a Creative Commons Attribution 4.0 International License, which permits use, sharing, adaptation, distribution and reproduction in any medium or format, as long as you give appropriate credit to the original author(s) and the source, provide a link to the Creative Commons licence, and indicate if changes were made. The images or other third party material in this article are included in the article's Creative Commons licence, unless indicated otherwise in a credit line to the material. If material is not included in the article's Creative Commons licence and your intended use is not permitted by statutory regulation or exceeds the permitted use, you will need to obtain permission directly from the copyright holder. To view a copy of this licence, visit http://creativecommons.org/licenses/by/4.0/.

\section{References}

1. Aksu AE, Piper DJW (1979) Baffin Bay in the past 100,000 yr. Geology 7:245-248

2. Allan E, de Vernal A, Knudsen MF, Hillaire-Marcel C, Moros M, Ribeiro S, Ouellet-Bernier MM, Seidenkrantz MS (2018) Late
Holocene sea surface instabilities in the Disko Bay Area, West Greenland, in phase with delta O-18 oscillations at Camp Century. Paleoceanogr Paleoclimatol 33:227-243

3. Alley RB, Agustsdottir AM (2005) The 8k event: cause and consequences of a major Holocene abrupt climate change. Quat Sci Rev 24:1123-1149

4. Anderson NJ, Leng MJ (2004) Increased aridity during the early Holocene in West Greenland inferred from stable isotopes in laminated-lake sediments. Quat Sci Rev 23:841-849

5. Barber D, Marsden R, Minnett P, Ingram G, Fortier L (2001) Physical processes within the North Water (NOW) Polynya. Atmos Ocean 39:163-166

6. Bartels M et al (2017) Atlantic Water advection vs. glacier dynamics in northern Spitsbergen since early deglaciation. Climate Past 13(12):1717-1749

7. Belt ST, Masse G, Rowland SJ, Poulin M, Michel C, LeBlanc B (2007) A novel chemical fossil of palaeo sea ice: IP25. Org Geochem 38:16-27

8. Belt ST, Masse G, Vare LL, Rowland SJ, Poulin M, Sicre M-A, Sampei M, Fortier L (2008) Distinctive C-13 isotopic signature distinguishes a novel sea ice biomarker in Arctic sediments and sediment traps. Mar Chem 112:158-167

9. Belt ST, Smik L, Köseoğlu D, Knies J, Husum K (2019) A novel biomarker-based proxy for the spring phytoplankton bloom in Arctic and sub-arctic settings-HBI T25. Earth Planet Sci Lett 523:115703. https://doi.org/10.1016/j.eps1.2019.06.038

10. Belt ST (2018) Source-specific biomarkers as proxies for Arctic and Antarctic sea ice. Org Geochem 125:277-298

11. Belt ST et al (2017) Identification of C-25 highly branched isoprenoid (HBI) alkenes in diatoms of the genus Rhizosolenia in polar and sub-polar marine phytoplankton. Org Geochem 110:65-72

12. Belt ST, Cabedo-Sanz P, Smik L, Navarro-Rodriguez A, Berben SMP, Knies J, Husum K (2015) Identification of paleo Arctic winter sea ice limits and the marginal ice zone: optimised biomarker-based reconstructions of late Quaternary Arctic sea ice. Earth Planet Sci Lett 431:127-139

13. Belt ST, Müller J (2013) The Arctic sea ice biomarker IP25: a review of current understanding, recommendations for future research and applications in palaeo sea ice reconstructions. Quat Sci Rev 79:9-25

14. Bidle KD, Azam F (1999) Accelerated dissolution of diatom silica by marine bacterial assemblages. Nature 397:508-512

15. Blaauw M, Andres Christen J (2011) Flexible paleoclimate agedepth models using an autoregressive gamma process. Bayesian Anal 6:457-474

16. Boon JJ, Rijpstra WIC, Delange F, Deleeuw JW, Yoshioka M, Shimizu Y (1979) Black sea sterol-molecular fossil for dinoflagellate blooms. Nature 277:125-127

17. Bourgeois JC, Koerner RM, Gajewski K, Fisher DA (2000) A holocene ice-core pollen record from Ellesmere Island, Nunavut, Canada. Quat Res 54:275-283

18. Briner JP, Hakansson L, Bennike O (2013) The deglaciation and neoglaciation of Upernavik Isstrom, Greenland. Quat Res 80:459-467

19. Brown TA, Belt ST (2016) Novel tri- and tetra-unsaturated highly branched isoprenoid (HBI) alkenes from the marine diatom Pleurosigma intermedium. Org Geochem 91:120-122

20. Brown TA, Belt ST, Tatarek A, Mundy CJ (2014) Source identification of the Arctic sea ice proxy IP25. Nat Commun 5:4197. https://doi.org/10.1038/ncomms5197

21. Caron M, St-Onge G, Montero-Serrano JC, Rochon A, Georgiadis E, Giraudeau J, Massé G (2018) Holocene chronostratigraphy of northeastern Baffin Bay based on radiocarbon and palaeomagnetic data. Boreas 48(1):147-165. https://doi.org/10.1111/ bor.12346 
22. Caron M, Rochon A, Carlos J, Serrano M, Onge GST (2019) Evolution of sea-surface conditions on the northwestern Greenland margin during the Holocene. J Quat Sci. https://doi.org/10.1002/ jqs. 3146

23. Cazenave A, Remy F (2011) Sea level and climate: measurements and causes of changes. Wiley Interdiscip Rev Climate Change 2:647-662

24. Cavalieri J, Parkinson L, Gloersen P, Zwally J (1996) Sea Ice Concentrations from Nimbus-7 SMMR and DMSP SSM/ISSMIS Passive Microwave Data, Version 1. NASA National Snow and Ice Data Center Distributed Active Archive Center, Boulder (updated 2015). https://doi.org/10.5067/8GQ8LZQVL0VL. Accessed Aug 2017

25. Collins LG, Allen CS, Pike J, Hodgson DA, Weckstrom K, Masse G (2013) Evaluating highly branched isoprenoid (HBI) biomarkers as a novel Antarctic sea-ice proxy in deep ocean glacial age sediments. Quat Sci Rev 79:87-98

26. Cormier MA, Rochon A, de Vernal A, Gelinas Y (2016) Multiproxy study of primary production and paleoceanographical conditions in northern Baffin Bay during the last centuries. Mar Micropaleontol 127:1-10

27. Cronin TM, DeNinno LH, Polyak L, Caverly EK, Poore RZ, Brenner A, Rodriguez-Lazaro J, Marzen RE (2014) Quaternary ostracode and foraminiferal biostratigraphy and paleoceanography in the western Arctic Ocean. Mar Micropaleontol 111:118-133

28. de Vernal A, Gersonde R, Goosse H, Seidenkrantz MS, Wolff EW (2013) Sea ice in the paleoclimate system: the challenge of reconstructing sea ice from proxies-an introduction. Quat Sci Rev 79:1-8

29. de Vernal A, Hillaire-Marcel C, Darby DA (2005) Variability of sea ice cover in the Chukchi Sea (western Arctic Ocean) during the Holocene. Paleoceanography. https://doi. org/10.1029/2005pa001157

30. de Vernal A, Hillaire-Marcel C, Rochon A, Frechette B, Henry M, Solignac S, Bonnet S (2013) Dinocyst-based reconstructions of sea ice cover concentration during the Holocene in the Arctic Ocean, the northern North Atlantic Ocean and its adjacent seas. Quat Sci Rev 79:111-121

31. Dorschel B, Gebhardt AC, Hebbeln D, Sichha M (2015) BAFFEAST Past Greenland Ice Sheet dynamics, Palaeoceanography and Plankton Ecology in the Northeast Baffin BayCruise No. MSM44-June 30-July 30, 2015-Nuuk (Greenland)—Nuuk (Greenland), MARIA S. MERIAN. https://doi. org/10.2312/cr_msm2344

32. Dyke AS (2008) The Steens by inlet ice-streams in the context of the deglaciation of Northern Baffin Island, Eastern Arctic Canada. Earth Surf Proc Land 33:573-592

33. Dyke AS, Andrews JT, Clark PU, England JH, Miller GH, Shaw J, Veillette JJ (2002) The Laurentide and Innuitian ice sheets during the Last Glacial Maximum. Quat Sci Rev 21:9-31

34. Dyke AS, Hooper J, Savelle JM (1996) A history of sea ice in the Canadian Arctic Archipelago based on postglacial remains of the bowhead whale (Balaena mysticetus). Arctic 49:235-255

35. England J, Atkinson N, Bednarski J, Dyke AS, Hodgson DA, Cofaigh CO (2006) The Innuitian Ice Sheet: configuration, dynamics and chronology. Quat Sci Rev 25:689-703

36. Fahl K, Stein R (2012) Modern seasonal variability and deglacial/Holocene change of central Arctic Ocean sea-ice cover: new insights from biomarker proxy records. Earth Planet Sci Lett 351:123-133

37. Fisher DA, Koerner RM (2003) Holocene ice-core climate history-a multi-variable approach. In: Mackay A, Battarbee $\mathrm{R}$, Birks J, Oldfield F (eds) Global change in the Holocene, pp 281-292
38. Funder S, Goosse H, Jepsen H, Kaas E, Kjaer KH, Korsgaard NJ, Larsen NK, Linderson H, Lysa A, Moller P, Olsen J, Willerslev E (2011) A 10,000-year record of Arctic ocean sea-ice variabilityview from the beach. Science 333:747-750

39. Georgiadis E, Giraudeau J, Martinez P, Lajeunesse P, St-Onge G, Schmidt S, Masse G (2018) Deglacial to postglacial history of Nares Strait, Northwest Greenland: a marine perspective from Kane Basin. Climate Past 14:1991-2010

40. Gersonde R, Crosta X, Abelmann A, Armand L (2005) Sea-surface temperature and sea ice distribution of the Southern Ocean at the EPILOG Last Glacial Maximum - a circum-Antarctic view based on siliceous microfossil records. Quat Sci Rev 24:869-896

41. Hansen KE, Giraudeau J, Wacker L, Pearce C, Seidenkrantz MS (2020) Reconstruction of Holocene oceanographic conditions in the Northeastern Baffin Bay. Climate Past Discuss 2020:1-34

42. Hillaire-Marcel C, de Vernal A (2008) Stable isotope clue to episodic sea ice formation in the glacial North Atlantic. Earth Planet Sci Lett 268:143-150

43. Holland MM, Bitz CM, Tremblay B (2006) Future abrupt reductions in the summer Arctic sea ice. Geophys Res Lett. https://doi. org/10.1029/2006g1028024

44. Humlum O (1985) The glaciation level in West Greenland. Arct Alp Res 17:311-319

45. Jackson R, Carlson AE, Hillaire-Marcel C, Wacker L, Vogt C, Kucera M (2017) Asynchronous instability of the North American-Arctic and Greenland ice sheets during the last deglaciation. Quat Sci Rev 164:140-153

46. Jennings A, Andrews J, Pearce C, Wilson L, Olfasdotttir S (2015) Detrital carbonate peaks on the Labrador shelf, a 13-7 ka template for freshwater forcing from the Hudson Strait outlet of the Laurentide Ice Sheet into the subpolar gyre. Quat Sci Rev 107:62-80

47. Jennings A, Andrews J, Wilson L (2011) Holocene environmental evolution of the SE Greenland Shelf North and South of the Denmark Strait: Irminger and East Greenland current interactions. Quat Sci Rev 30:980-998

48. Jennings A, Sheldon C, Cronin T, Francus P, Stoner J, Andrews J (2011) The Holocene history of Nares Strait: transition from Glacial Bay to Arctic-Atlantic throughflow. Oceanography 24:26-41

49. Jennings AE (1993) The Quaternary history of Cumberland Sound, southeastern Baffin-Island-the marine evidence. Geogr Phys Quat 47:21-42

50. Jennings AE, Knudsen KL, Hald M, Hansen CV, Andrews JT (2002) A mid-Holocene shift in Arctic sea-ice variability on the East Greenland Shelf. Holocene 12:49-58

51. Jennings AE, Walton ME, Cofaigh CO, Kilfeather A, Andrews JT, Ortiz JD, De Vernal A, Dowdeswell JA (2014) Paleoenvironments during Younger Dryas-Early Holocene retreat of the Greenland Ice Sheet from outer Disko Trough, central west Greenland. J Quat Sci 29:27-40

52. Jennings AE, Andrews JT, Oliver B, Walczak M, Mix A (2019) Retreat of the Smith Sound Ice Stream in the Early Holocene. Boreas 48:825-840

53. Jones PD, Osborn TJ, Briffa KR (2001) The evolution of climate over the last millennium. Science 292:662-667

54. Joughin I, Smith BE, Howat IM, Scambos T, Moon T (2010) Greenland flow variability from ice-sheet-wide velocity mapping. J Glaciol 56:415-430

55. Justwan A, Koc N, Jennings AE (2008) Evolution of the Irminger and East Icelandic Current systems through the Holocene, revealed by diatom-based sea surface temperature reconstructions. Quat Sci Rev 27:1571-1582

56. Kaufman DS, Ager TA, Anderson NJ, Anderson PM, Andrews JT, Bartlein PJ, Brubaker LB, Coats LL, Cwynar LC, Duvall 
ML, Dyke AS, Edwards ME, Eisner WR, Gajewski K, Geirsdottir A, Hu FS, Jennings AE, Kaplan MR, Kerwin MN, Lozhkin AV, MacDonald GM, Miller GH, Mock CJ, Oswald WW, Otto-Bliesner BL, Porinchu DF, Ruhland K, Smol JP, Steig EJ, Wolfe BB (2004) Holocene thermal maximum in the western Arctic (0-180 degrees W). Quat Sci Rev 23:529-560

57. Kinnard C, Zdanowicz CM, Fisher DA, Isaksson E, de Vernal A, Thompson LG (2011) Reconstructed changes in Arctic sea ice over the past 1,450 years. Nature 479:509-U231

58. Knies J, Cabedo-Sanz P, Belt ST, Baranwal S, Fietz S, RosellMele A (2014) The emergence of modern sea ice cover in the Arctic Ocean. Nat Commun. https://doi.org/10.1038/ncomm s6608

59. Knudsen KL, Stabell B, Seidenkrantz MS, Eiriksson J, Blake W (2008) Deglacial and Holocene conditions in northernmost Baffin Bay: sediments, foraminifera, diatoms and stable isotopes. Boreas 37:346-376

60. Kolling HM, Stein R, Fahl K, Perner K, Moros M (2017) Short-term variability in late Holocene sea ice cover on the East Greenland Shelf and its driving mechanisms. Palaeogeogr Palaeoclimatol Palaeoecol 485:336-350

61. Kolling HM (2017) Decadal to centennial variability of (sub-) Arctic sea ice distribution and its paleoenvironmental significance. $\mathrm{PhD}$ thesis, University of Bremen

62. Kolling HM, Stein R, Fahl K, Perner K, Moros M (2018) New insights into sea ice changes over the past $2.2 \mathrm{kyr}$ in Disko Bay. West Greenland. Arktos 4(1):11

63. Krawczyk DW, Witkowski A, Lloyd J, Moros M, Harff J, Kuijpers A (2013) Late-Holocene diatom derived seasonal variability in hydrological conditions off Disko Bay, West Greenland. Quat Sci Rev 67:93-104

64. Krawczyk DW, Witkowski A, Moros M, Lloyd JM, Hoyer JL, Miettinen A, Kuijpers A (2017) Quantitative reconstruction of Holocene sea ice and sea surface temperature off West Greenland from the first regional diatom data set. Paleoceanography 32: $18-40$

65. Kremer A, Stein R, Fahl K, Ji Z, Yang Z, Wiers S, Matthiessen J, Forwick M, Lowemark L, O'Regan M, Chen J, Snowball I (2018) Changes in sea ice cover and ice sheet extent at the Yermak Plateau during the last $160 \mathrm{ka}$ - Reconstructions from biomarker records. Quat Sci Rev 182:93-108

66. Kutzbach J, Webb T, Roberts N, Wright HE, Ruddiman W, Street-Perrott F, Bartlein R (1993) Global climates since the last glacial maximum, Vegetational, lake-level, and climatic history of the Near East and Southwest Asia. University of Minnesota Press, New York, pp 194-220

67. Lasher GE, Axford Y (2019) Medieval warmth confirmed at the Norse Eastern Settlement in Greenland. Geology 47:267-270

68. Laskar J, Robutel P, Joutel F, Gastineau M, Correia ACM, Levrard B (2004) A long-term numerical solution for the insolation quantities of the Earth. Astron Astrophys 428:261-285

69. Lecavalier BS, Milne GA, Simpson MJ, Wake L, Huybrechts P, Tarasov L, Kjeldsen KK, Funder S, Long AJ, Woodroffe SA, Dyke AS, Larsen NK (2014) A model of Greenland ice sheet deglaciation constrained by observations of relative sea level and ice extent. Quat Sci Rev 102:54-84

70. Ledu D, Rochon A, de Vernal A, Barletta F, St-Onge G (2010) Holocene sea ice history and climate variability along the main axis of the Northwest Passage, Canadian Arctic. Paleoceanography 25

71. Levac E, De Vernal A, Blake W (2001) Sea-surface conditions in northernmost Baffin Bay during the Holocene: palynological evidence. J Quat Sci 16:353-363

72. Leventer A (1998) The fate of Antarctic "Sea Ice Diatoms" and their use as paleoenvironmental indicators. Antarctic Research Series, pp 121-137
73. Limoges A, Ribeiro S, Weckstrom K, Heikkila M, Zamelczyk K, Andersen TJ, Tallberg P, Masse G, Rysgaard S, NorgaardPedersen N, Seidenkrantz MS (2018) Linking the modern distribution of biogenic proxies in high Arctic Greenland shelf sediments to sea ice, primary production, and Arctic-Atlantic inflow. J Geophys Res Biogeosci 123:760-786

74. Ljungqvist FC (2010) A New reconstruction of temperature variablity in the extra-Tropical Northern Hemisphere during the last two millennia. Geografiska Annaler Series Phys Geogr 92A:339-351

75. Lochte AA, Repschläger J, Seidenkrantz M-S, Kienast M, Blanz T, Schneider RR (2019) Holocene water mass changes in the Labrador Current. Holocene. https://doi.org/10.1177/09596 83618824752

76. Lloyd J, Moros M, Perner K, Telford RJ, Kuijpers A, Jansen E, McCarthy D (2011) A $100 \mathrm{yr}$ record of ocean temperature control on the stability of Jakobshavn Isbrae, West Greenland. Geology 39:867-870

77. Lloyd JM, Park LA, Kuijpers B, Moros M (2005) Early holocene palaeoceanography and deglacial chronology of Disko Bay, West Greenland. Quat Sci Rev 24:1741-1755

78. Lloyd JM, Kuijpers A, Long A, Moros M, Park LA (2007) Foraminiferal reconstruction of mid- to late-Holocene ocean circulation and climate variability in Disko Bugt, West Greenland. Holocene 17:1079-1091

79. Long AJ, Roberts DH (2002) A revised chronology for the 'Fjord Stade' moraine in Disko Bay, west Greenland. J Quat Sci 17:561-579

80. Long AJ, Roberts DH (2003) Late Weichselian deglacial history of Disko Bay, West Greenland, and the dynamics of the Jakobshavns Isbrae ice stream. Boreas 32:208-226

81. Massé G, Belt ST, Sicre MA (2010) Arctic sea ice: high resolution reconstructions, Iceland in the Central Northern Atlantic: hotspot, sea currents and climate change, May 2010, Plouzané.

82. Matero ISO, Gregoire LJ, Ivanovic RF, Tindall JC, Haywood AM (2017) The 8.2 ka cooling event caused by Laurentide ice saddle collapse. Earth Planet Sci Lett 473:205-214

83. Matthiessen J, de Vernal A, Head M, Okolodkov Y, Zonneveld K, Harland R (2005) Modem organic-walled dinoflagellate cysts in arctic marine environments and their (paleo-) environmental significance. Paläontologische Zeitschrift 79:3-51

84. Melling H, Gratton Y, Ingram G, Melling H, Gratton Y, Ingram G (2010) Ocean circulation within the North Water polynya of Baffin Bay Ocean Circulation within the North Water Polynya of Baffin Bay. Atmos Ocean 39(3):301-325. https://doi. org/10.1080/07055900.2001.9649683

85. Moros M, Lloyd JM, Perner K, Krawczyk D, Blanz T, de Vernal A, Ouellet-Bernier M-M, Kuijpers A, Jennings AE, Witkowski A, Schneider R, Jansen E (2016) Surface and sub-surface multiproxy reconstruction of middle to late Holocene palaeoceanographic changes in Disko Bay, West Greenland. Quat Sci Rev 132:146-160

86. Mudie PT, Rochon A, Prins MA, Soenarjo D, Troelstra S, Scott DB, Roncaglia L, Kuijpers A (2004) Late Pleistocene-Holocene marine geology of Nares Strait region: palaeoceanography from foraminifera and dinoflagellate cysts, sedimentology and stable isotopes. Polarforschung 74:69-183

87. Müller J, Masse G, Stein R, Belt ST (2009) Variability of seaice conditions in the Fram Strait over the past 30,000 years. Nat Geosci 2:772-776

88. Müller J, Stein R (2014) High-resolution record of late glacial and deglacial sea ice changes in Fram Strait corroborates iceocean interactions during abrupt climate shifts. Earth Planet Sci Lett 403:446-455

89. Müller J, Wagner A, Fahl K, Stein R, Prange M, Lohmann G (2011) Towards quantitative sea ice reconstructions in the 
northern North Atlantic: a combined biomarker and numerical modelling approach. Earth Planet Sci Lett 306:137-148

90. Navarro-Rodriguez A, Belt ST, Knies J, Brown TA (2013) Mapping recent sea ice conditions in the Barents Sea using the proxy biomarker IP25: implications for palaeo sea ice reconstructions. Quat Sci Rev 79:26-39

91. Nesje A, Dahl SO (2001) The Greenland 8200 cal. yr BP event detected in loss-on ignition profiles in Norwegian lacustrine sediment sequences. J Quat Sci 16:155-166

92. Newton AMW, Knutz PC, Huuse M, Gannon P, Brocklehurst SH, Clausen OR, Gong Y (2017) Ice stream reorganization and glacial retreat on the northwest Greenland shelf. Geophys Res Lett 44:7826-7835

93. Norgaard-Pedersen N, Mikkelsen N (2009) 8000 year marine record of climate variability and fjord dynamics from Southern Greenland. Mar Geol 264:177-189

94. NSIDC (2018) National Snow and Ice Data Center (NSIDC)Arctic Sea Ice News and Analysis https://nsidc.org/

95. Ostermann LE, Nelson AR (1989) Latest Quaternary and Holocene paleocenography of the eastern Baffin Island continental shelf, Canada: Benthic foraminiferal evidence. Can J Earth Sci 26:2236-2248

96. Ouellet-Bernier MM, de Vernal A, Hillaire-Marcel C, Moros M (2014) Paleoceanographic changes in the Disko Bay area, West Greenland, during the Holocene. Holocene 24:1573-1583

97. Perner K, Moros M, Jennings A, Lloyd JM, Knudsen KL (2012) Holocene palaeoceanographic evolution off West Greenland. Holocene 23:374-387

98. Pieńkowski AJ, Gill NK, Furze MF, Mugo SM, Marret F, Perreaux A (2017) Arctic sea-ice proxies: Comparisons between biogeochemical and micropalaeontological reconstructions in a sediment archive from Arctic Canada. Holocene 27:665-682

99. Porter SE, Mosley-Thompson ES (2011) Extracting a history of Baffin Bay Sea ice extent from West Central Greenland Ice Cores. In: AGU fall meeting abstracts

100. Reimer PJ, Bard E, Bayliss A, Beck JW, Blackwell PG, Ramsey CB, Buck CE, Cheng H, Edwards RL, Friedrich M, Grootes PM, Guilderson TP, Haflidason H, Hajdas I, Hatte C, Heaton TJ, Hoffmann DL, Hogg AG, Hughen KA, Kaiser KF, Kromer B, Manning SW, Niu M, Reimer RW, Richards DA, Scott EM, Southon JR, Staff RA, Turney CSM, van der Plicht J (2013) INTCAL13 and Marine13 radiocarbon age calibration curves $0-50,000$ years cal BP. Radiocarbon 55:1869-1887

101. Ren J, Jiang H, Seidenkrantz MS, Kuijpers A (2009) A diatombased reconstruction of Early Holocene hydrographic and climatic change in a southwest Greenland fjord. Mar Micropaleontol 70:166-176

102. Rignot $E$, Kanagaratnam $P$ (2006) Changes in the velocity structure of the Greenland ice sheet. Science 311:986-990

103. Ribeiro S et al (2017) Sea ice and primary production proxies in surface sediments from a High Arctic Greenland fjord: Spatial distribution and implications for palaeoenvironmental studies. Ambio 46:S106-S118

104. Rochon A, de Vernal A, Turon JL et al (1999) Distribution of recentdinoflagellate cysts in surface sediments from the North AtlanticOcean and adjacent seas in relation to sea-surface parameters. Am Assoc Stratigr Palynol Contrib Ser 35:1-146

105. Sadler HE (1976) Water, Heat, and Salt transports through Nares Strait, Ellesmere Island. J Fish Res Board Can 33:2286-2295

106. Sakshaug E (2004) Primary and secondary production in the Arctic seas. In: Stein R, Macdonald RW (eds) The organic carbon cycle in the Arctic Ocean, vol 80. Springer, Berlin, pp 57-82

107. Seidenkrantz M-S (2013) Benthic foraminifera as palaeo sea-ice indicators in the subarctic realm - examples from the Labrador Sea-Baffin Bay region. Quat Sci Rev 79:135-144
108. Seidenkrantz MS, Roncaglia L, Fischel A, Heilmann-Clausen C, Kuijpers A, Moros M (2008) Variable North Atlantic climate seesaw patterns documented by a late Holocene marine record from Disko Bugt, West Greenland. Mar Micropaleontol 68:66-83

109. Sheldon C, Jennings A, Andrews JT, Cofaigh CO, Hogan K, Dowdeswell JA, Seidenkrantz MS (2016) Ice stream retreat following the LGM and onset of the west Greenland current in Uummannaq Trough, west Greenland. Quat Sci Rev 147:27-46

110. Shemesh A, Burckle LH, Froelich PN (1989) Dissolution and preservation of Antarctic diatoms and the effect on sediment thanatocoenoses. Quat Res 31:288-308

111. Slabon P, Dorschel B, Jokat W, Myklebust R, Hebbeln D, Gebhardt C (2016) Greenland ice sheet retreat history in the northeast Baffin Bay based on high-resolution bathymetry. Quatern Sci Rev 154:182-198

112. Smik L, Cabedo-Sanz P, Belt ST (2016) Semi-quantitative estimates of paleo Arctic sea ice concentration based on source-specific highly branched isoprenoid alkenes: a further development of the PIP25 index. Org Geochem 92:63-69

113. Stern HL, Heide-Jorgensen MP (2003) Trends and variability of sea ice in Baffin Bay and Davis Strait, 1953-2001. Polar Res 22:11-18

114. Stroeve J, Notz D (2018) Changing state of Arctic sea ice across all seasons. Environ Res Lett 13(10):23

115. St-Onge MP, St-Onge G (2014) Environmental changes in Baffin Bay during the Holocene based on the physical and magnetic properties of sediment cores. J Quat Sci 29:41-56

116. Stein R, Fahl K (2013) Biomarker proxy shows potential for studying the entire Quaternary Arctic sea ice history. Org Geochem 55:98-102

117. Stein R, Fahl K, Schreck M, Knorr G, Niessen F, Forwick M, Gebhardt C, Jensen L, Kaminski M, Kopf A, Matthiessen J, Jokat W, Lohmann G (2016) Evidence for ice-free summers in the late Miocene central Arctic Ocean. Nat Commun 7:1-13

118. Stroeve JC, Serreze MC, Holland MM, Kay JE, Malanik J, Barrett AP (2012) The Arctic's rapidly shrinking sea ice cover: a research synthesis. Climat Change 110:1005-1027

119. Tang CCL, Ross CK, Yao T, Petrie B, DeTracey BM, Dunlap E (2004) The circulation, water masses and sea-ice of Baffin Bay. Prog Oceanogr 63:183-228

120. Thomas EK, Briner JP, Ryan-Henry JJ, Huang YS (2016) A major increase in winter snowfall during the middle Holocene on western Greenland caused by reduced sea ice in Baffin Bay and the Labrador Sea. Geophys Res Lett 43:5302-5308

121. Trouet V, Esper J, Graham NE, Baker A, Scourse JD, Frank DC (2009) Persistent positive North Atlantic oscillation mode dominated the Medieval climate anomaly. Science 324:78-80

122. Vare LL, Masse G, Gregory TR, Smart CW, Belt ST (2009) Sea ice variations in the central Canadian Arctic Archipelago during the Holocene. Quat Sci Rev 28:1354-1366

123. Vinther BM, Buchardt SL, Clausen HB, Dahl-Jensen D, Johnsen SJ, Fisher DA, Koerner RM, Raynaud D, Lipenkov V, Andersen KK, Blunier T, Rasmussen SO, Steffensen JP, Svensson AM (2009) Holocene thinning of the Greenland ice sheet. Nature 461:385-388

124. Vinther BM, Clausen HB, Johnsen SJ, Rasmussen SO, Andersen KK, Buchardt SL, Dahl-Jensen D, Seierstad IK, Siggaard-Andersen ML, Steffensen JP, Svensson A, Olsen J, Heinemeier J (2006) A synchronized dating of three Greenland ice cores throughout the Holocene. J Geophys Res Atmos. https://doi.org/10.1029/2005jd006921

125. Volkman JK (1986) A review of sterol markers for marine and terrigenous organic matter. Org Geochem 9:83-99

126. Volkman JK, Barrett SM, Blackburn SI, Mansour MP, Sikes EL, Gelin F (1998) Microalgal biomarkers: a review of recent research developments. Org Geochem 29:1163-1179

127. Wacker L, Fueloep RH, Hajdas I, Molnar M, Rethemeyer J (2013) A novel approach to process carbonate samples for radiocarbon 
measurements with helium carrier gas. Nucl Instrum Methods Phys Res Sect B Beam Interact Mater Atoms 294:214-217

128. Walsh JE, Chapman WL (2001) Twentieth-century sea ice variations from observational data. Ann Glaciol 33(1):444-448

129. Wanner H, Solomina O, Grosjean M, Ritz SP, Jetel M (2011) Structure and origin of Holocene cold events. Quat Sci Rev 30:3109-3123

130. Wang M et al (2012) A sea ice free summer Arctic within 30 years: an update from CMIP5 models. Geophys Res Lett. https://doi. org/10.1029/2012gl052868

131. Warren CR (1992) Iceberg calving and the glacioclimatic record. Prog Phys Geogr Earth Environ 16:253-282
132. Weidick A, Bennike O (2007) Quaternary glaciation history and glaciology of Jakobshavn Isbrae and the Disko Bay region, West Greenland: a review. Geol Surv Denmark Greenland Bull 14:7

133. Wood M, Rignot E, Fenty I, Menemenlis D, Millan R, Morlighem $\mathrm{M}$ et al (2018) Ocean-induced melt triggers glacier retreat in Northwest Greenland. Geophys Res Lett 45:8334-8342

134. Xiao X, Fahl K, Mueller J, Stein R (2015) Sea-ice distribution in the modern Arctic Ocean: biomarker records from trans-Arctic Ocean surface sediments. Geochim Cosmochim Acta 155:16-29

Publisher's Note Springer Nature remains neutral with regard to jurisdictional claims in published maps and institutional affiliations. 